\title{
Clitics in imperative: proclisis, enclisis and mesoclisis in Albanian and in Italo-Romance varieties of Lausberg area
}

\author{
Benedetta Baldi and Leonardo M. Savoia \\ University of Florence, Italy
}

\begin{abstract}
The relation between morpho-syntactic structure and its externalization into interpretive levels is the topic of this article. In many languages, typically in Romance and Albanian varieties, modal contexts, specifically imperative and infinitive, and negation, give rise to phenomena of clitic reordering and an interesting micro-variation. Imperative differs from declarative sentences in selecting enclisis except in negative contexts. Moreover, in Albanian mesoclisis appears in the $2^{\text {nd }}$ plural person of imperative, between the verbal base and the person inflection. A similar distribution characterizes Calabro-Lucanian varieties spoken in Lausberg area, in contact with Arbëresh (Italo-Albanian) dialects. This article proposes to analyze the influence of modal contexts on the lexicalization of object clitics (OCls) and their different behavior in connection to their referential properties. Our descriptive and theoretical starting point is the representational morpho-syntactic approach adopted in Manzini and Savoia (2011 and subsequent works; see Section 5).
\end{abstract}

Keywords: imperative mood, mesoclisis, negative contexts, Albanian varieties, Romance varieties

\section{Introduction}

In this article, we will investigate some Albanian and Italo-Romance varieties that share mesoclisis in imperatives, i.e. the insertion of object clitics between the root and the inflection. The Albanian varieties include the Gheg spoken in Shkodër, the Tosk of Gjirokastër and the Arbëresh (Italo-Albanian) varieties of Firmo (Calabria), San Costantino Albanese (Basilicata), Greci (Campania) and San Marzano di San Giuseppe (Apulia). As to the Italo-Romance dialects, we have dealt with the imperative forms of Terranova Pollino and Senise (Basilicata), and Morano (Calabria), all belonging to the so-called Lausberg area, i.e. the conservative Romance area on the border between Basilicata and Calabria and surrounding the Pollino Massif, also including a number of Arbëresh villages in contact conditions. Finally, in order to substantiate our analysis, the doubling of object clitics in the North Apulian dialect of San Severo, and the imperative inflection in the South Calabrian dialect of Cardeto will be 
examined. As is known from the literature, all of these varieties possess a system of object clitics that occur in proclisis in declarative sentences and in enclisis in imperatives, and, in some Romance languages, also in infinitive contexts. Here, we will analyze the distribution of OCls in imperative, as being a clue to understand its syntactic properties.

\section{Imperative mood: A non-veridical form}

Imperatives are strictly linked to a specific illocutionary force, an act of command (Aikhenvald 2010), addressed to the recipient. The reference to the latter provides the content for the interpretation of the subject. In other words, the subject of the imperatives is the recipient of the locutory production in the context of the speech act. So, the imperative generally excludes tense distinctions, insofar as it is deictically anchored to the discourse universe. Naturally, formal properties of the verb vary across languages, depending on their inflectional organization, so that in many languages imperative can coincide with the lexical base/root of the verb, whereas in others imperative is in turn endowed with person-specialized morphology (Aikhenvald 2010, Alcázar and Saltarelli 2014).

From a typological perspective, imperatives show the reversal of the more generally assumed markedness scale between $1^{\text {st }}$ and $2^{\text {nd }}$ person, in the sense that "third person is marked, while second person is often unmarked, particularly in the singular" (Alcázar and Saltarelli 2014: 41). Aikhenvald (2010: 76) schematizes the continuum from non-canonical (left) to canonical (right) 'person distinction' in imperative in the scale in (1):

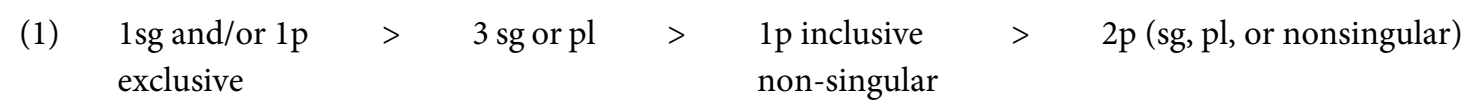

Thus, imperative overturns the markedness hierarchy underlying assertion/declarative sentences, in which $1^{\text {st }}$ person subjects introduce the less marked type of references. This is evidenced by languages with subject clitics where it is the $1^{\text {st }}$ person clitic pronoun that most frequently can be missing in the paradigm (cf. Manzini and Savoia 2005, forthcoming).

Both syntax and semantics of imperatives raised some debated issues. Platzack and Rosengren (1998: 192), assuming a cartographic approach, conclude that imperatives imply a sentence structure lacking the anchoring to the tense, mood and finiteness projections, usually characterizing declaratives and interrogatives, whereby " $[t]$ he absence of FinP prevents the imperative clause both from referring to the event expressed and from containing a proper subject". The gist is that the order establishes a connection between the 'prominent argument of the sentence', the addressee to whom the order is given, and the event referred to by the proposition. Nevertheless, the non-finite nature of imperatives does not exempt them from presenting agreement properties independently of the modal and temporal specifications. All things considered, the crucial imperative property is the fact that the eventive content of the verbal lexical element is not associated to temporal or other referential morphosyntactic devices.

From a semantic point of view, imperatives introduce a clause that escapes the truth conditions generally applicable to declaratives (Giannakidou 1998). According to Portner 
(2004) imperatives lexicalize a property rather than an event. In a nutshell, a very usual analysis is that the imperative form assigns a property to a prominent argument, identified with the addressee (Platzak and Rosengren 1998, Mauck and Zanuttini 2005). This identification is governed by the association via Merge (Mauck and Zanuttini 2005) of the prepositional argument with the Addressee selected by the Speech Act. This mechanism is explained in Zanuttini (2008: 196) by postulating that the imperative is the head of a JussiveP projection, which "has an operator in its specifier that... takes as input a proposition, consisting of the predicate saturated by the subject, and yields as output a property. This property has a presupposition that its argument, corresponding to the subject, refers to the addressee(s)." In other words, in the imperative a modal operator connects the situation denoted by the sentence in its scope to the hearer denotation.

Leaving out the structural solutions adopted in the literature, we agree with the proposal that the imperative denotes a property "which can only be true of the addressee" (Portner 2004: 239), rather than an event, and as such submitted to veridicality requirements. Schematizing, the idea of Mauck and Zanuttini (2005) is that imperative is a predicate with an unsaturated variable $x$ bound by the $\lambda$ operator introduced by the modal element as in (2), where $f i x$ is the $2^{\text {nd }}$ person imperative form coinciding with the verbal root exemplified in (3a).

(2) $\quad \int \mathrm{ix}$

$\lambda x$, see $(x, y)$

Naturally, the expressed (or covert) agreement of imperatives coincides with the features identifying the addressee - in many languages this is externalized by specialized inflectional exponents (Aikhenvald 2010, Alcázar and Saltarelli 2014), as in the case of the inflection of $2^{\text {nd }}$ plural -te in Standard Italian and many Romance dialects, $-n i$ in Albanian varieties. This raises an interesting issue, since the $2^{\text {nd }}$ person inflection and object clitics lexicalize referential properties, possibly undergoing truth conditions, contrasting with the counterfactual nature of the imperative. This discrepancy can be seen as the reason for clitics in imperative clauses to be lexicalized by specialized forms in comparison with declarative ones (Manzini and Savoia 2017).

\section{Clitic distribution in imperatives: Albanian}

The micro-variation among Tosk (Ghirokastër), Gheg (Shkodër) and Arbëresh varieties primarily involves the position of object clitics separating varieties allowing for total mesoclisis, as Albanian Tosk in (3), partial mesoclisis, as generally Arbëresh dialects of Italy in (4-5-6), or selectively preventing mesoclisis, as Shkodër Gheg in (7). Positive imperatives are exemplified in (a) $-\left(a^{\prime}\right)$ for $2^{\text {nd }}$ singular and (b)-(b') $2^{\text {nd }}$ plural forms. (a)-(b) illustrate the insertion of a $3^{\text {rd }}$ person clitic, (a')-(b') illustrate the insertion of the $1^{\text {st }}$ person clitic, $(c)-\left(c^{\prime}\right)$ exemplify the $1^{\text {st }}$ person $+3^{\text {rd }}$ person accusative clusters and $(d)-\left(d^{\prime}\right)$ the $3^{\text {rd }}$ person dative $+3^{\text {rd }}$ person accusative clusters. As to the inflection of the imperative, it is of note that the $2^{\text {nd }}$ singular person coincides with the root of the verb, whereas the $2^{\text {nd }}$ plural person has the morpheme of $2^{\text {nd }}$ plural $-n i$, as in fixni! 'see ( $2^{\text {nd }}$ plural)!', silni! 'bring ( $2^{\text {nd }}$ plural)!' (Gjirokastër) (for a comparison, see the negative forms in (8)). The $1^{\text {st }}$ plural clitic is generally avoided or, eventually, it occurs before 
the verb, although mesoclisis or enclisis seem to be accepted by some speakers, as exemplified in (e). The data in (f) illustrate the structures where the dative clitic $i$ is inserted alone; in this variety it occurs in mesoclisis like the other $3^{\text {rd }}$ person clitics. Finally, for the sake of completeness, we present $\mathrm{OCl}$ in pre-verbal position in declaratives, precisely accusatives in (g), dative in (g') and reflexive/unaccusative in (g") (cf. Manzini and Savoia 2007). It is of note that generally the $3^{\text {rd }}$ singular person $\mathrm{OCl}$ is realized by the alternant $\varepsilon$ in isolation and by the alternant $-a$ in clusters oblique-accusative, as shown by the comparison between $(3-7 \mathrm{a}, \mathrm{b})$ and $(3-7 c, d)$.

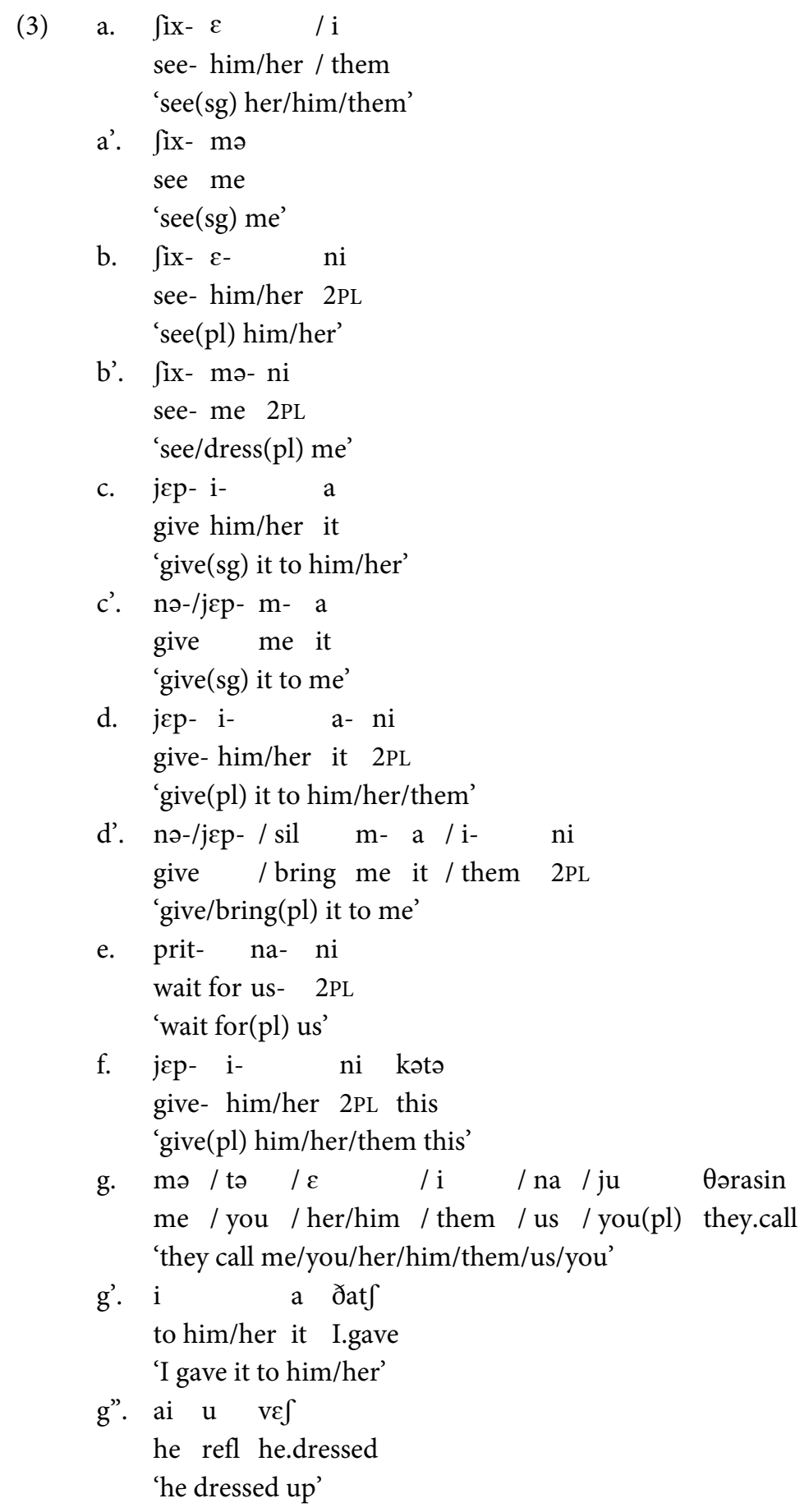


Differently from Tosk varieties, in Arbëresh dialects, in the case of the clitic string dative+accusative deictic clitics ( $1^{\text {st }}$ person) are incorporated inside the word, while the $3^{\text {rd }}$ person clitics are inserted on the right of the inflection. The following data come from the varieties of Firmo (Calabria) in (4) and San Costantino Albanese (Lucania) in (5). The simple occurrence of dative in ( $f$ ), is obscured by the coalescence of the dative $-i$ and the final vowel of the ending $-n i$, suggesting that its position is the same as the other $3^{\text {rd }}$ person elements.

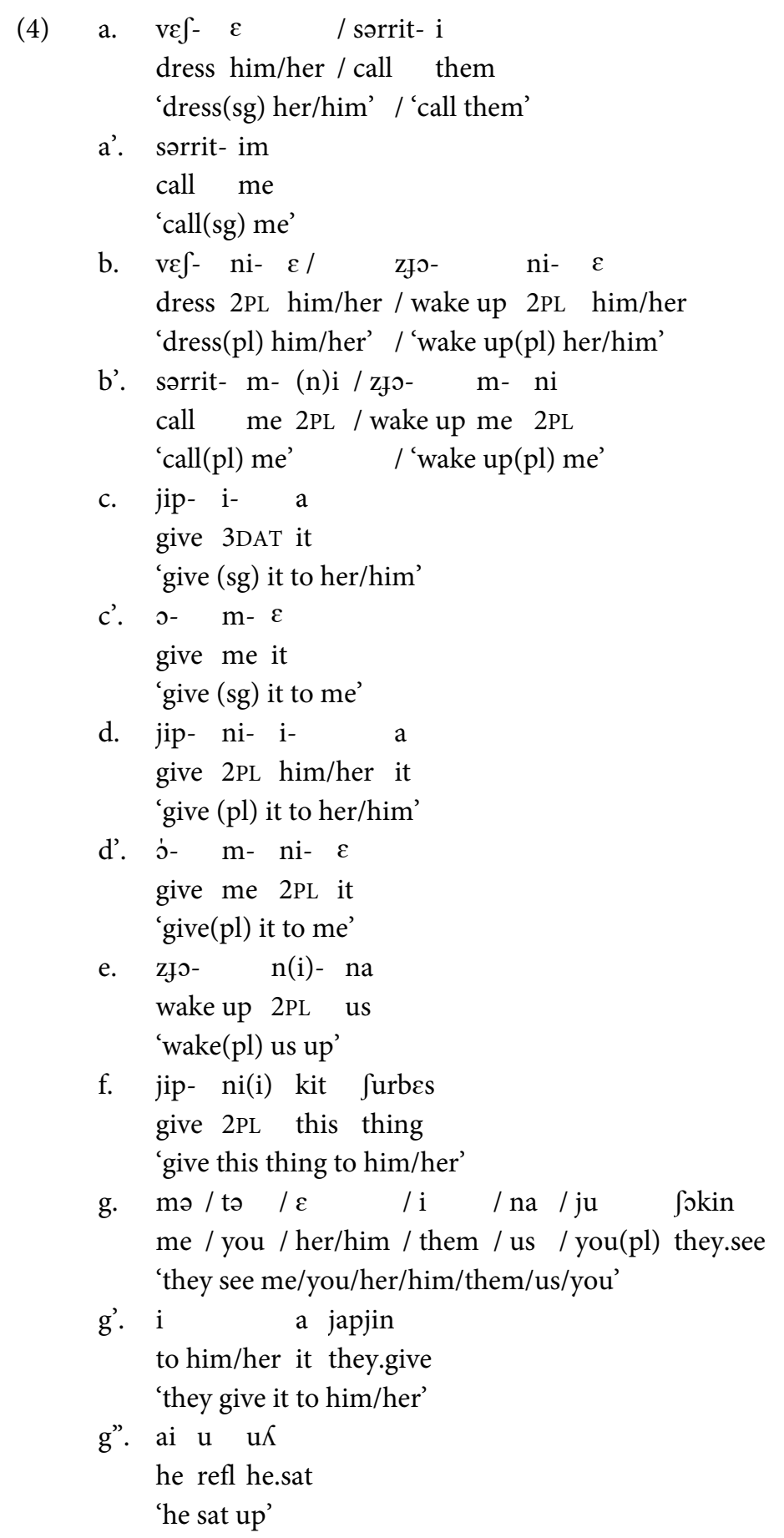

(5) a. sicl- $\varepsilon \quad / \mathrm{i}$

bring him/her / them

'bring(sg) her/him/them (towards the speaker)' 


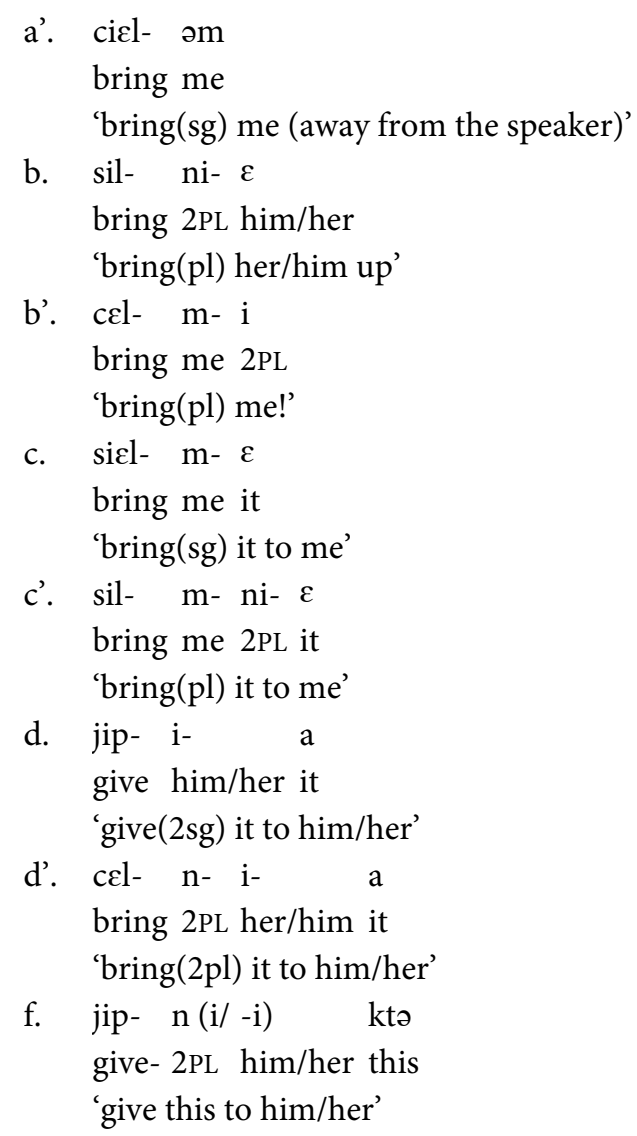

San Costantino

It is worth noting that in (5) the $2^{\text {nd }}$ plural person of imperative presents two alternants $-i$ and $-n i$, the first of which is the usual inflection of the $2^{\text {nd }}$ plural person of indicative. In the imperative $-n i$ becomes obligatory in mesoclisis contexts, where it is preceded by the deictic $1^{\text {st }}$ person clitic.

Some differences emerge in Arbëresh dialects. In Greci, the accusative clitic follows the imperative, as in (6a), whereas the $1^{\text {st }}$ person clitic precedes it, as in (6b). When they combine, the $1^{\text {st }}$ person clitic is in mesoclisis, while the accusative is inserted in enclisis.

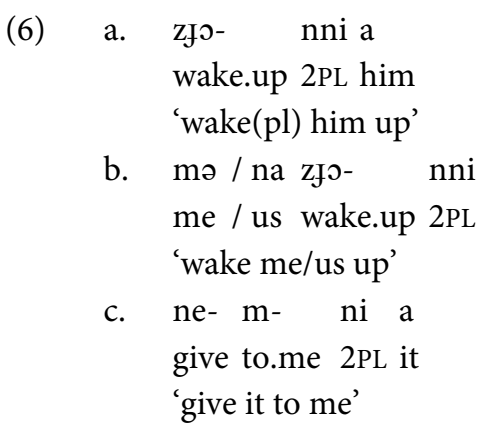

Greci

In the Gheg variety spoken in Shkodër, the $1^{\text {st }}$ person clitics and clitic clusters $1^{\text {st }}$ person $+3^{\text {rd }}$ person occur in pre-verbal position, in this differentiating from the preceding varieties, which insert $1^{\text {st }}$ person clitics in enclisis or in mesoclisis. $3^{\text {rd }}$ person clitics and $3^{\text {rd }}$ person clusters (accusative and dative) occur in post-verbal position, or, variably, in mesoclisis. We note that in $2^{\text {nd }}$ plural forms with the $3^{\text {rd }}$ person cluster $j-a$ ' 3 dat +3 acc' the duplication of the $2^{\text {nd }}$ plural 
inflection is attested, as in (7d). Moreover, in Shkodër variety the cluster $i$ - $a$ doubles a lexical object so that we do not find the lexicalization of the simple dative $i$ (cf. (3d)).

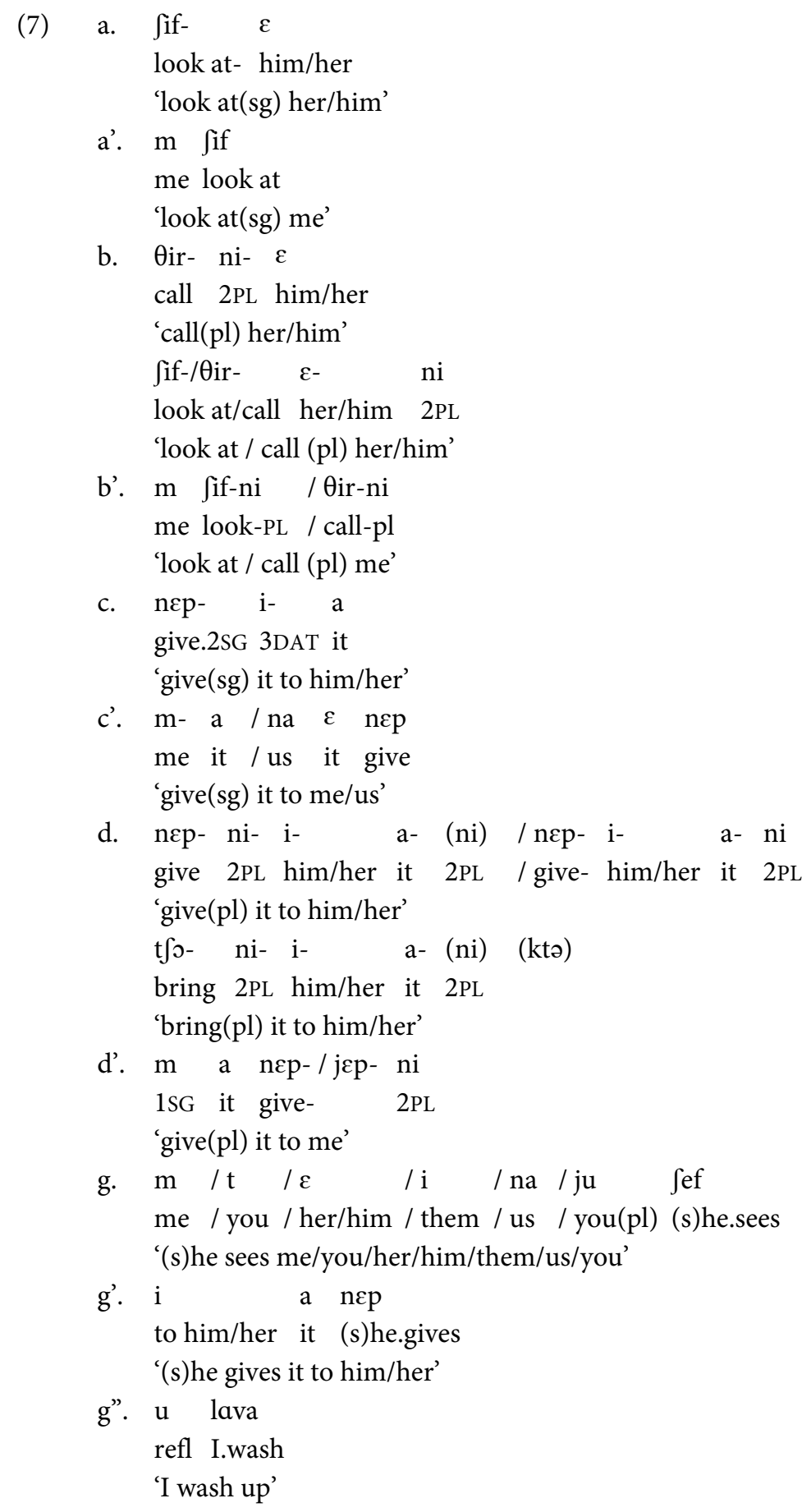

What is to note is that the order between deictic and $3^{\text {rd }}$ person clitics is substantially preserved as in other varieties, in the sense that deictic clitics occupy a position in a domain more to the left than the $3^{\text {rd }}$ person clitics. This distribution is realized by placing deictic clitics before the verb and $3^{\text {rd }}$ person clitics inside or to the right of the verbal form. 
Negative imperatives involve a specialized negation mos/mas occurring in other modal contexts, and entail clitics to be inserted pre-verbally, in proclitic position, before all persons. The negation precedes the clitic string and the following verb, as illustrated in (8).

(8) mos i- a jep
neg him/her it give
'do not give(sg) it to him'
mos m- a sil- ni
neg me- it bring- 2PL
'do not bring(pl) it to me'

mos i- $\quad$ a $/ m-\varepsilon$ jip-ni

Gjirokastër

neg him/her it / me it give-2PL

'do not give(pl) it to him/me'

mos na zjo- ni

neg us wake up 2PL

'do not wake(pl) us up

$\operatorname{mos} \mathrm{m} \quad \varepsilon$ si $\mathrm{l}$

neg me it bring-2sG

'do not bring (sg) it to me'

mos $m \quad \varepsilon$ sil-ni/sil-i / jip-i

neg me it bring-2PL / give-2PL

'do not bring/give(pl) it to me'

mas $\varepsilon \quad / \mathrm{m}$ jif / / jif-ni

neg him/her / me look-2sG / look-2PL

'do not look at (sg/pl) her/him/me'

mas $\mathrm{m} / \mathrm{i}$ a nep / nep-ni

neg me / him/her it give-2sG / PL

'do not give(sg/pl) it to me / to her/him'

Firmo

San Costantino

Shkodër

In the Arbëresh of San Marzano (Apulia) (cf. Manzini and Savoia 1999, 2007), otherwise showing the split between $1^{\text {st }}$ person and $3^{\text {rd }}$ person clitics on a par with the other Arbëresh varieties, cf. (8a), in negative contexts the object clitic is doubled in pre-verbal and enclitic position, as in (9b).

(9) a. hua- nni- i- a

tell 2PL him it

'tell(2pl) it to him/her'

hua- mmə- ni- $\varepsilon$

tell me 2PL it

'tell(2pl) it to me'

b. mosə $\mathrm{m} \varepsilon$ hua-nni- $\varepsilon$

not me it tell-2PL it

'do not tell it to me'

mos i a hua-nni- i- a

not him it tell-2PL him it

'do not tell(2pl) it to him' 
Note that we have focused on the canonical $2^{\text {nd }}$ person addressee forms of imperative (Kuryłowicz 1964), while we have left out the inclusive (you and I) $1^{\text {st }}$ plural person. In Tosk and Gheg varieties, the $1^{\text {st }}$ plural forms are realized by subjunctive forms, as in (10), introduced by the modal particle to (MPrt), and the negation, in turn, implies the modal form mos/mas. In Arbëresh varieties we find the indicative form or the deontic periphrasis have+inflected verb, as illustrated in (10'); in the negative contexts the declarative contexts negation nayg 'not' occurs.

(10) (mos) t a vesh- im neg MPrt him/her dress 1PL 'do not dress him/her'

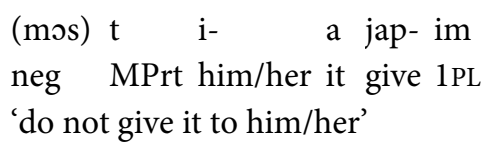

Gjirokastër

Shkodër

(10') (nəyg) (ke- mi) i- a jam- mi

neg (have 1PL) him/her it give 1PL

'we (do not) have to give it to him/her'

Firmo

$$
\text { (mos) i- a jap-mi }
$$

neg him/her it give-1PL

'do not give it to him/her'

San Costantino

In Albanian, $1^{\text {st }}$ person inclusive is realized by subjunctive, as in (10), whereas in Southern Italian dialects illustrated here, the speaker inclusive form is not differentiated, as in Standard Italian. We recall that in the varieties we investigate in this article, only $2^{\text {nd }}$ person may select a specialized form, not necessarily coinciding with the root; in the other cases we find forms coinciding with the corresponding ones of present indicative or, in the case of $1^{\text {st }}$ inclusive in Albanian, with subjunctive.

Resorting to subjunctive in non-canonical persons, specifically $1^{\text {st }}$ plural, is a widespread strategy for imperative. The general difficulty or impossibility for languages to have imperatives addressed to $1^{\text {st }}$ and $3^{\text {rd }}$ persons is overcome by using counterfactual forms such as exhortative and subjunctive (Aikhenvald 2010, Alcázar and Saltarelli 2014). As we saw in Section 2, imperative introduces a speech act interpretation whereby the only admitted subject is the recipient of the interaction, typically the $2^{\text {nd }}$ person addressee. This restriction is reflected not only interpretively, excluding self-ascription ( $1^{\text {st }}$ person addressee), but also structurally, entailing asymmetry between speaker and recipient (Alcázar and Saltarelli 2014: 106). 


\subsection{Non-Active imperative forms}

In non-active forms of imperative the middle-reflexive or passive interpretation is generally lexicalized by the non-active (NA) clitic $u$ (oneself; Manzini and Savoia 2007), characterizing passive, middle and reflexive forms of the verb also in the perfect and, according to the different varieties, in other tenses. In the imperative, the position of $u$ is similar to that of the $3^{\text {rd }}$ person clitics. In fact, $u$ is in enclisis in the $2^{\text {nd }}$ singular imperative, as illustrated in (11a)-(11'a). In the $2^{\text {nd }}$ plural person in (11b)-(11'b), it occurs in mesoclisis in Gjirokastër and in enclisis in Shkodër variety. The negative form in (11a',b')-(11'a',b') involves the reordering with the result that the modal negation mos precedes the sequence clitic $\mathrm{u}+$ verb. The data of Gjirokastër highlights the fact that differently from consonant roots, vocalic roots such as la- 'wash' select the middlereflexive infix $-h$ -

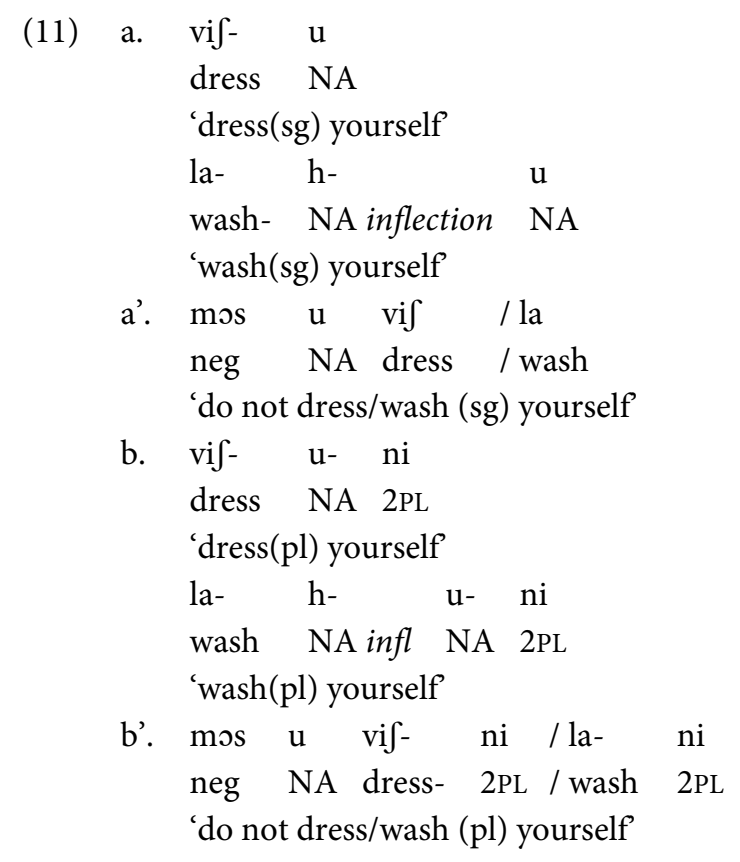

Gjirokastër

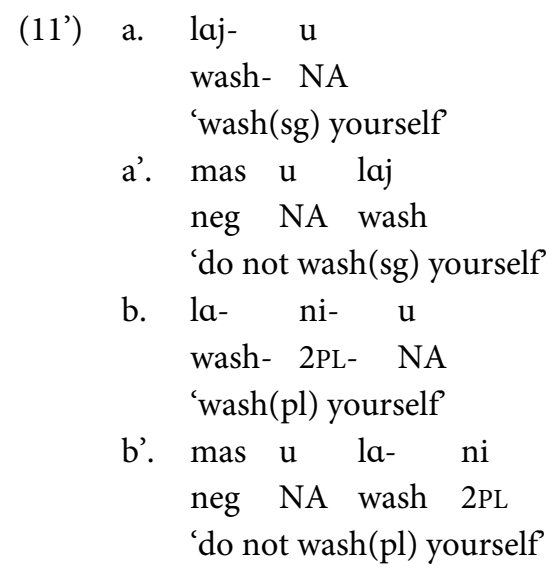

Shkodër

In Albanian varieties, the middle-reflexive morpheme $-h-\varepsilon$ is inserted between the vocalic root and the inflection, while consonantal roots exclude $-h$ - and generally select a specialized root 
internal vocalic alternant. Summarizing, in $2^{\text {nd }}$ plural middle-reflexive, imperatives in (11b) introduce the active inflection, while the middle-reflexive reading is lexicalized by the NA clitic, so excluding the middle-reflexive specialized infixes.

Differently from the Albanian varieties spoken in Balkan area, in Arbëresh dialects the internal structure of $2^{\text {nd }}$ person plural of the middle-reflexive imperative illustrated in (12b) coincides with the $2^{\text {nd }}$ person plural of the middle-reflexive indicative. More precisely, the vocalic root is followed by the middle-reflexive infix, $-h$ - in San Costantino dialect, $-k-\varepsilon$ in the one of Firmo, followed in turn by the person ending.

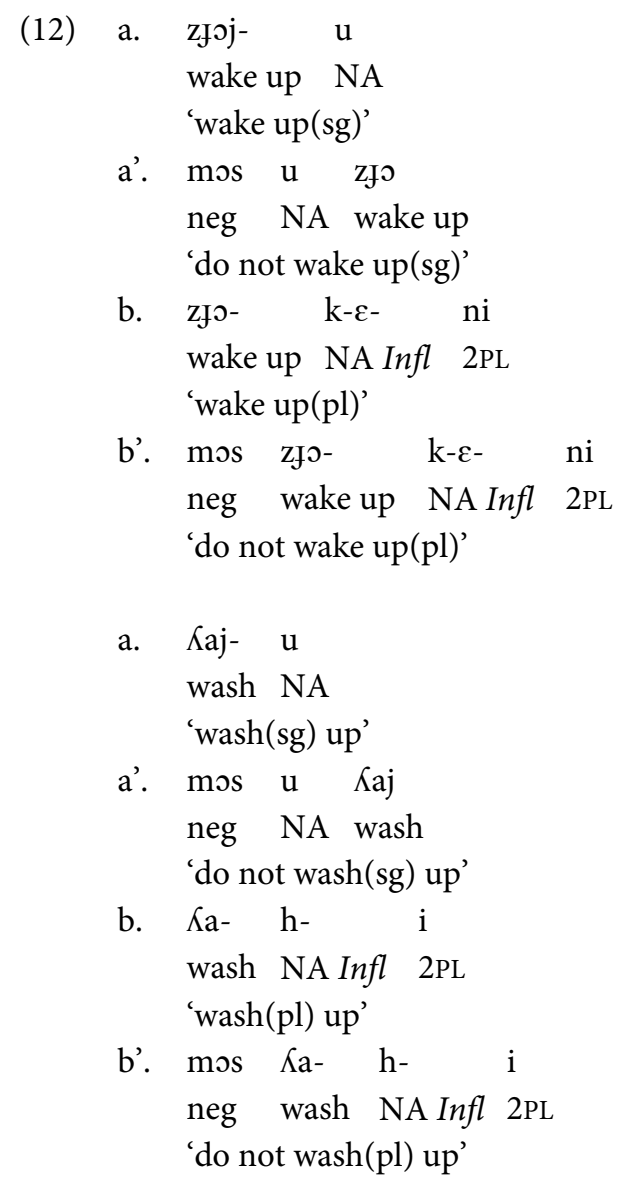

In negative imperative the clitic $u$ is reordered before the verb and preceded by the modal negation, as in $\left(12 \mathrm{a}^{\prime}, \mathrm{b}^{\prime}\right)$, in the singular, while in negative $2^{\text {nd }}$ plural the middle-reflexive indicative form is preserved, so that non-active interpretation is entirely devolved to the NA inflection $-h-,-k-$.

\subsection{An intermediate summary}

The phenomena we have described encompass the following points:

- Mesoclisis is attested in $2^{\text {nd }}$ person plural form of imperative in Arbëresh and in Gheg (Shkodër) and Tosk (Gjirokastër) varieties of Albania.

- In Arbëresh varieties, mesoclisis affects only the $1^{\text {st }}$ person singular form; $3^{\text {rd }}$ person and NA clitics follow the imperative. 
- In Gjirokastër variety, mesoclisis involves both $1^{\text {st }}$ singular and $3^{\text {rd }}$ person clitics.

- In Shkodër variety, $1^{\text {st }}$ person clitics precede the imperative and mesoclisis involves only $3^{\text {rd }}$ person and NA clitics.

Before addressing the interaction between the distribution of person elements, the different behavior of clitics and imperative form, some distributional phenomena concerning Southern Italian dialects will be considered. This comparison will shed light on the principles regulating the differential distribution of clitics and inflections in imperatives.

\section{Mesoclisis and reordering in Lausberg area dialects}

Calabro-Lucanian Lausberg area dialects are characterized by a distribution of clitics in imperative very similar to the one of contact Arbëresh varieties. In (13-14), data are provided from a Lucanian variety (Terranova Pollino) and a North Calabrian variety (Morano). In these dialects, unlike Albanian varieties, mesoclisis involves dative and locative clitics in addition to the $1^{\text {st }} / 2^{\text {nd }}$ person forms and is restricted to the contexts where the $3^{\text {rd }}$ person clitic occurs in enclisis. In other words, it affects only deictic/dative/locative clitics $+3^{\text {rd }}$ person clitics clusters. ${ }^{1}$ In (13a) $-(14 a) 2^{\text {nd }}$ singular forms are provided, in (13b, b')-(14b) $1^{\text {st }}$ plural forms and in (13c)(14c) $2^{\text {nd }}$ plural ones. At least in some of these dialects enclitic forms of clusters in $1^{\text {st }} / 2^{\text {nd }}$ plural are variably realized, as exemplified in (13c'). (13d) and (14d) illustrate the postverbal position of the simple object clitics. Finally, in these dialects, as in general in Italian dialects, $1^{\text {st }}$ plural imperative is normally attested and admits mesoclisis. The examples in (13e)-(14e) illustrate the object clitics occurring in proclisis to the verb in declarative sentences. These are realized by the simple inflectional elements $a, u, i$ 'her, him, them', unlike the more complex structure of enclitic forms. We recall that in these dialects the clitic no lexicalizes both partitive and dative, as in $n u$ 'ðっпаðə '(s)he gives it to him/her' (Terranova), $n u$ rongu 'I give it to her/him' (Morano). ${ }^{2}$

(13) a. ðon-a- m'm / n'n- illə/a:

give-TV me / him/her it

'give it to $\mathrm{me} / \mathrm{him} / \mathrm{her}$ '

b. mənd-a- 'tf- iə-m- a:

put- TV LOC TV-1PL it

'let us put it here'

1 In these dialects the dative is realized by the clitic $n \rrbracket$, syncretic with the partitive clitic (Manzini and Savoia 2005).

2 For a better understanding of the examples from Lausberg area dialects in (13-14), we note the following: these dialects generally present two alternants for the verb 'give', a monosyllabic base from $d a-(r e)$, and another one from don-a-(re); in several South Lucanian varieties, the II, III and IV verbal classes share the Thematic Vowel (TV) -e-, diphthongizing to -i区- in some dialects, like in Terranova Pollino, cf. yra'piatasa 'you open'; monosyllabic verbs optionally insert analogical forms based on avere 'have', such as $1^{\text {st }}$ plural forms

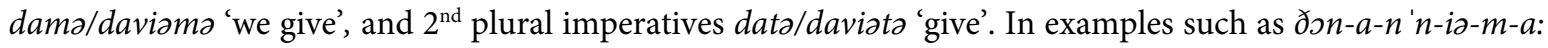

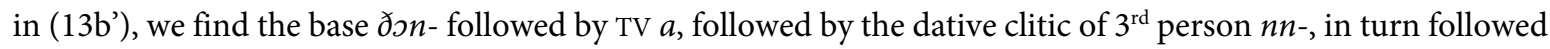
by a thematic element -iz-introducing the $1^{\text {st }}$ plural inflection $m$, finally followed by the $\mathrm{OCl}$ of $3^{\text {rd }}$ person with phonetic form $a$ : due to the velarization of the original $l$. 

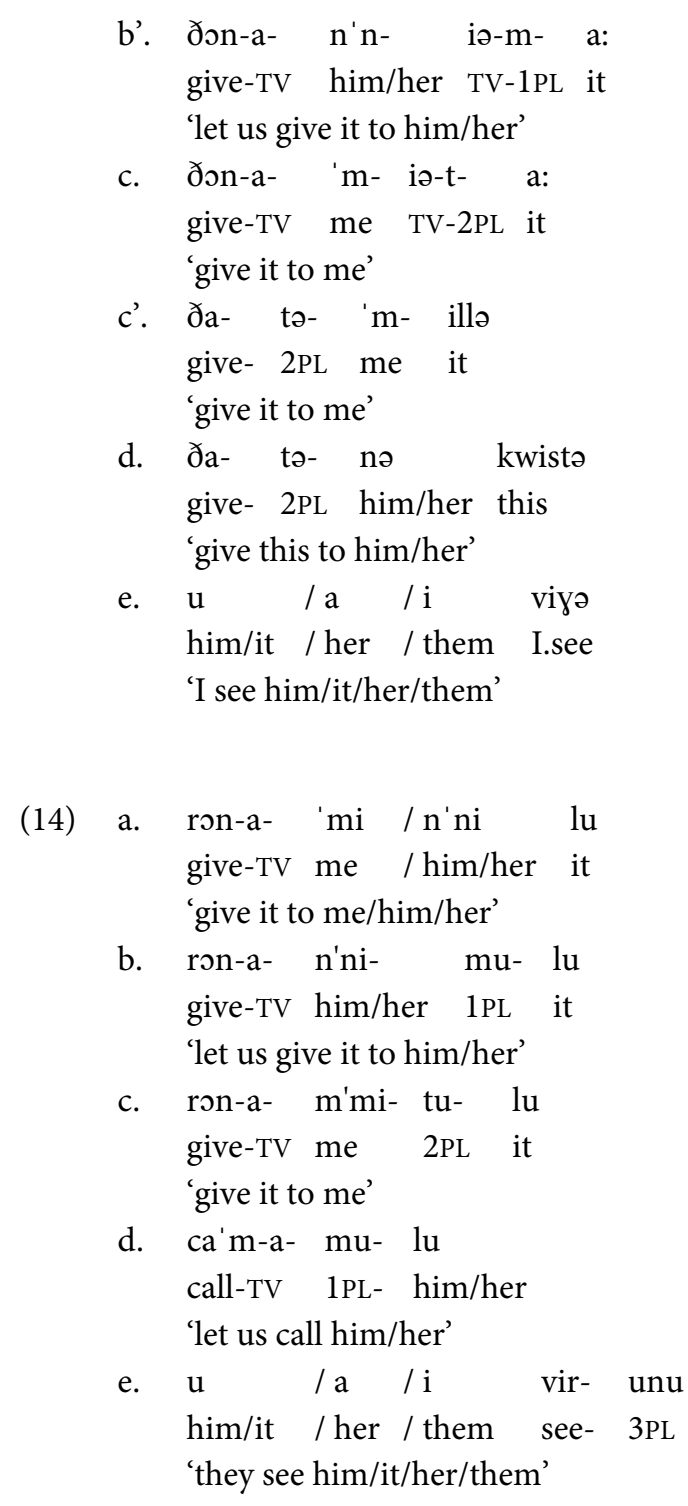

Morano Calabro

As noted, the morphology of $3^{\text {rd }}$ person OCls in enclisis includes the $l$-root characterizing D elements in Romance languages (Manzini and Savoia 2017). Terranova dialect in (13) shows also the morpho-phonological alternant $-a$ : deriving from the velarization of original $l$-. In proclisis $3^{\text {rd }}$ person clitics coincide with the bare gender/number inflection, as in (13e)-(14e).

The enclitic elements attract the main stress of the word, as shown in the examples in (1314). The prosodic reorganization triggered by the positioning of the main stress in the enclitic forms gives rise to a trochaic foot such as dona-m ' $m$-illa 'give mi it' (Terranova Pollino), or an antepenultimate stressed string, such as rona-m'mi-tu-lu 'give (pl) it to me' (Morano). In both contexts, it is the first clitic of the cluster that is lexically designated to attract the stress. The result is that a left-headed foot is created which is followed by a final reduced foot in $1^{\text {st }} / 2^{\text {nd }}$ plural forms of imperatives, as in (15).

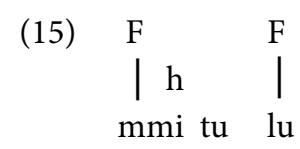


Re-assignment of the main stress can be connected to the specialized nature of $3^{\text {rd }}$ person clitics in post-verbal position in imperatives, where, following Manzini and Savoia (2017), the richer morphology is connected with the necessity to externalize a stronger referential import.

In the same way as in Albanian varieties, negative contexts imply the proclitic occurrence of pronominal forms, as exemplified in (16a-c) and (17a-c). Specifically, we find the $3^{\text {rd }}$ person $l$ - forms, in (16a) and (17a), i.e. the forms occurring in the position adjacent to the negative marker also in negative declaratives. As to the imperative form, in negative contexts the $2^{\text {nd }}$ singular is lexicalized by the infinitive, exactly like Standard Italian, as in (16a) and (17a). In the other persons the usual person inflection occurs, as in $(16 \mathrm{~b}, \mathrm{c})$ and $(17 \mathrm{~b}, \mathrm{c})$, where tv stands for Thematic Vowel.

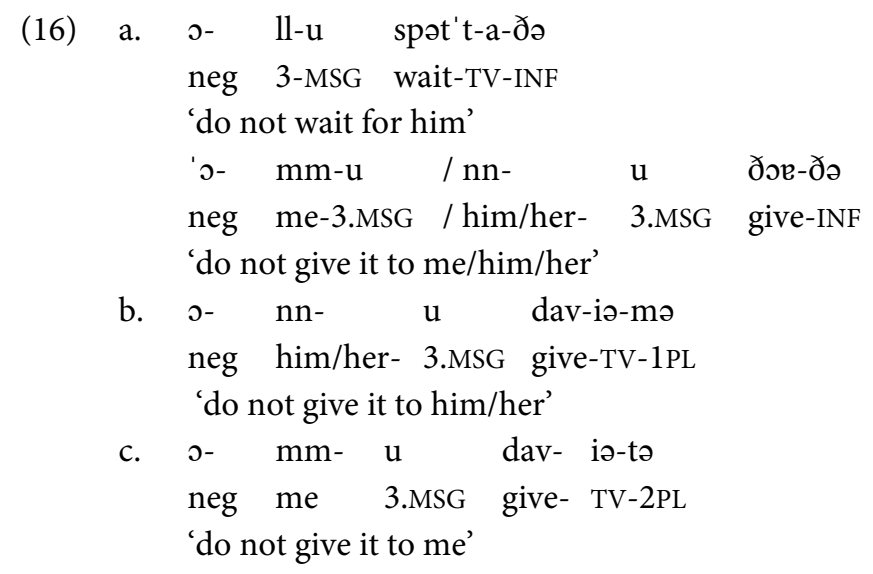

Terranova Pollino

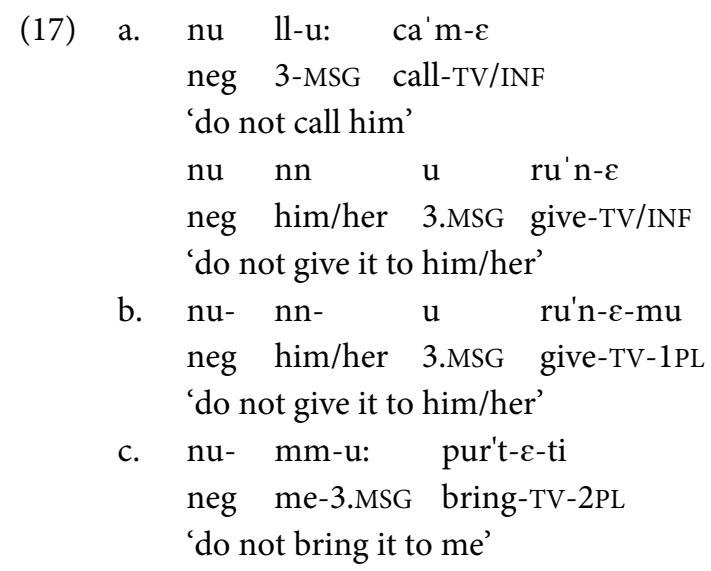

Morano

Summarizing, we see that:

- Mesoclisis is triggered only when dative/locative $/ 1^{\text {st }}$ person $+3^{\text {rd }}$ person clitics clusters are inserted in $1^{\text {st }}$ and $2^{\text {nd }}$ plural forms of imperative, unlike Albanian varieties, where mesoclisis is not limited to the clitic clusters.

- Dative/locative and $1^{\text {st }}$ person clitics occur between root and inflection while accusatives occur on the right of inflection.

- Negative imperatives are characterized by the same type of reordering as the one observed in Albanian varieties, whereby clitics and clitic clusters are inserted between the negation and the verb, in proclisis. 
- In this dialects the enclitic form of accusatives is different from the proclitic elements, specifically including the definiteness lexical base $l$-, missing in proclitic elements.

- The enclitic forms attract the main stress of word as exemplified in (15).

- $l$ - clitics occur also when preceded by the negation.

\subsection{Other cases of interaction between root, inflection and clitics in imperative}

Before concluding this section, we will extend the comparison to two other phenomena in which imperative imposes a special lexicalization of referential formatives, clitics or inflection. This requirement is clearly manifested by the occurrence of $1^{\text {st }}$ person clitic or clitic clusters in Albanian varieties in (3-7) between the root and the inflection. What is more, some varieties provide evidence for duplication of the argumental positions, inflectional or clitics, externalized in two copies. This is the case of the reduplicative structures of Shkodër in (7d), e.g. ncp-ni-j-a(ni) 'give-2pl-him/her-it(-2pl), give it to him/her', where is the inflectional morpheme that occurs in a position adjacent to the root and in a position on the right. Similar duplicative structures are documented in Lucanian and Calabrian dialects with mesoclisis in (13-14) (Manzini and Savoia 2005, 2011). More precisely, we find both duplication of the inflection, as in the Shkodër examples, in (18a), and the duplication of the clitic, as in (18b).

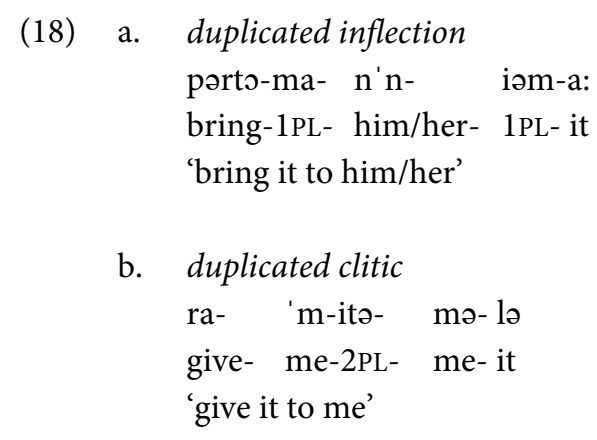

Terranova Pollino

Senise (Lucania)

A partially different condition is the one documented by San Costantino in (5), where the $2^{\text {nd }}$ person plural of imperative introduces - $n i$ in contexts with clitics, so that the simplex form sil-i

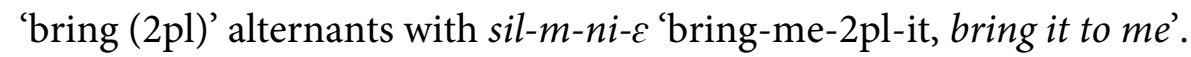

Reduplication of clitics is independently attested in Apulian and Lucanian varieties. For instance, in the North-Apulian dialect of San Severo in monosyllabic $2^{\text {nd }}$ singular person imperatives two copies of the first clitic of a cluster occur, as in (19a,a') (Manzini and Savoia 2005). (19b) illustrates the negative imperative with proclisis and (19c,c') the multisyllabic forms, excluding reduplication.

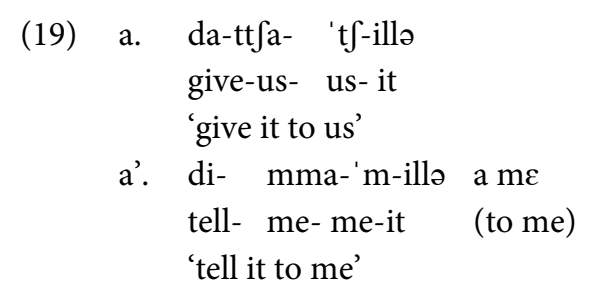




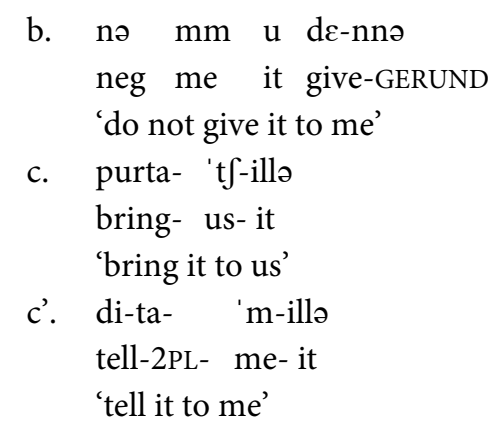

San Severo (Apulia)

As we see, a morpho-phonological restriction limits reduplication to the combination monosyllabic root+clitic cluster. However, the point is that the duplication of the clitic object is made possible by the imperative, suggesting that imperative introduces a domain on its right able to host object clitics.

As the last case study, we consider the extension of the infinitival inflection -rito the $1^{\text {st }}$ and $2^{\text {nd }}$ plural inflected forms in negative imperatives in some South Calabrian dialects. As we saw in Section 4, negative imperatives realize the $2^{\text {nd }}$ person singular by means of the verbal infinitive. In the dialect of Cardeto (and other neighbouring villages in South Calabria, cf. Ledgeway et al. 2016) -ri occurs in the $2^{\text {nd }}$ singular, in (20b), and is extended also to the other forms, as in (20b') for $1^{\text {st }}$ plural person and (20b") for $2^{\text {nd }}$ plural person. (20a,a',a") illustrate positive imperatival forms of $2^{\text {nd }}$ singular, $1^{\text {st }}$ plural and $2^{\text {nd }}$ plural.

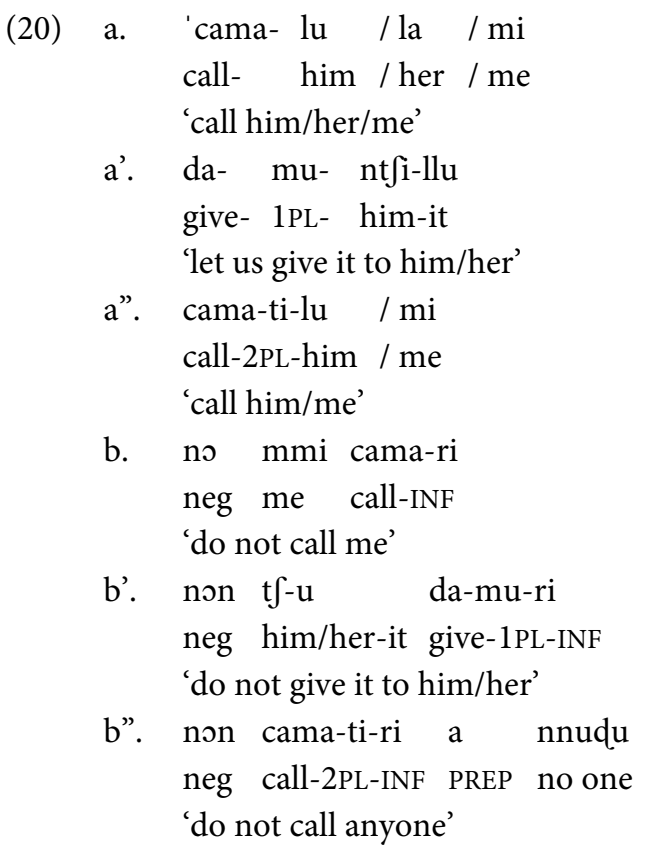

Again, the imperative domain seems to be able to include a richer inflectional structure than the other verbal forms, admitting a duplicated insertion of inflectional material. The specialized occurrence of -ri in Cardeto and adjacent dialects has been addressed in Loporcaro (1995), Ledgeway et al. (2016), de Angelis (online). While keeping to different theoretical approaches, the authors assume that the insertion of - $r i$ in the negative imperatives is due to an analogical leveling whereby the negative forms have re-established the parallel between the $2^{\text {nd }}$ singular 
person and the other ones. According to Ledgeway et al. (2016) this could derive from the contact with Greco imperative paradigm, where also the plural has dedicated forms. Loporcaro (1995) connects the leveling with the pattern of the positive form, that includes only two distinct morphologies (see the discussion in de Angelis online). What we can conclude is that the extension of -ri maybe depends on an analogical process, although its cause does not seem clear.

\section{The structure of lexical elements and the theoretical framework}

The asymmetries highlighted by the different distribution of clitics in positive and negative imperatives put into play some of the crucial morpho-syntactic properties of the sentence: the Phase structure of the imperative, the referential properties of the pronominal elements and the interpretive nature of the negation:

- DOM effects emerge, whereby deictic clitics ( $1^{\text {st }}$ person) have a different distribution from $3^{\text {rd }}$ person clitics at least in Shkodër and Arbëresh varieties.

- The $1^{\text {st }}$ person clitics precede the $3^{\text {rd }}$ person clitics in all contexts (mesoclisis/postverbal/pre-verbal).

- Negation requires clitics to occur in pre-verbal position (Manzini and Savoia 2007, 2011, 2017; Baldi and Savoia 2018)

Let us begin by considering the differential distribution of clitics. The table (19) schematizes the distribution of object clitics in the $2^{\text {nd }}$ person plural in (3-7) and in (13-14). In (21), 'msc' indicates the insertion in mesoclisis; the preverbal position is marked by 'prv' and the postverbal position by 'psv'. We remind that Albanian non-active clitic $u$ and the dative $i$ have the same distribution as the object clitics. As to mesoclisis in the Romance dialects we have considered, the phenomenon implies the co-occurrence of the accusative in enclisis, suggesting a partially different mechanism. Moreover, in these dialects mesoclisis involves also the locative form $t$ o 'here' syncretic for the $1^{\text {st }}$ plural person ' $u$ ', and the $3^{\text {rd }}$ person dative na 'to.him/her'.

\begin{tabular}{|c|c|c|c|c|}
\hline & $1^{\text {st }} \mathrm{sg}$ & $3^{\text {rd }}$ acc/dat/NA & $1^{\text {st }} \mathrm{sg}+3^{\mathrm{rd}} \mathrm{acc}$ & $3^{\text {rd }}$ dat $+3^{\text {rd }}$ acc \\
\hline Gjirokastër & $\mathrm{msc}$ & $\mathrm{msc}$ & $\mathrm{msc}$ & $\mathrm{msc}$ \\
\hline Arbëresh & $\mathrm{msc}$ & psv & $\mathrm{msc}$ & psv \\
\hline Shkodër & prv & $\mathrm{msc} / \mathrm{psv}$ & prv & $\mathrm{msc} / \mathrm{psv}$ \\
\hline Terranova P. & psv & psv & $\operatorname{msc}\left(1^{\mathrm{st}}\right)$ & $\operatorname{msc}$ (dat/Loc) \\
\hline Morano & psv & psv & $\operatorname{msc}\left(1^{\mathrm{st}}\right)$ & msc (dat/Loc) \\
\hline
\end{tabular}

The most immediate generalization evidenced by (22) concerns the reciprocal distribution of the clitics in imperatives, whereby we have the following ordering, in (22):

Deictic clitics/dative/locative $-3^{\text {rd }}$ Person and NA

The distributional variation in (3-7) and in (13-14), contrasting $1^{\text {st }}$ person objects with deictic content, and $3^{\text {rd }}$ person clitics, can be traced back to DOM Differential object marking phenomenon (Comrie 1979, Croft 1988, Bossong 1991). In the typological literature, the essence of DOM is that certain types of objects, of which participants in the discourse are the 
fundamental subset, are overtly marked (Aissen 2003, Bárány and Kalin in press). This phenomenon is treated in terms of referential properties, essentially animacy, definiteness and specificity, topicality expressed by means of a hierarchy regulating the distribution of grammatical functions in case systems (Dixon 1994, Kiparsky 2008, Aissen 2003, Bárány and Kalin in press), whereby the prominent elements in the scale are favoured in assuming the overt morphological mark. Depending on such basic factors, the prominence of $1^{\text {st }}$ and $2^{\text {nd }}$ person pronouns is easily derived. Specifically, the split between $1^{\text {st }}$ and $3^{\text {rd }}$ clitics seems to reflect their different interpretive status in relation to the syntactic representation of the pragmatic content (Speech Act in Speas and Tenny 2003). More precisely, deictic pronouns are interpreted independently of the event they are participants to, as anchoring to the discourse universe. $3^{\text {rd }}$ person elements (on a par with nouns) are anchored to the event introduced by the verb (Manzini and Savoia 2005, 2011), in other words, they are interpreted in relation with the argumental structure of the scene/action lexicalized by the verb.

In Albanian as well as in South Italian varieties ones, this difference is expressed by the fact that $1^{\text {st }}$ and $2^{\text {nd }}$ person OCls do not distinguish the accusative from the dative/oblique, but show the oblique form also in transitive contexts. Contrary, in Romance varieties, $3^{\text {rd }}$ person clitics separate accusative from oblique forms, while non-clitic $3^{\text {rd }}$ person forms lack any case morphology, see the pronouns jiddu/idda 'he/her' in Morano dialect. More precisely, $1^{\text {st }}$ person clitics are inserted in the string independently of their argumental role in the event (v, VP), and have an oblique form that, following Manzini et al. (in press), is required in order to be interpreted in the sentence. The idea is that the oblique is not selected by the verb but it is inherent to the DOM element, a sort of 'possessor' of the event. In any case, the oblique complies with the autonomous interpretation of DOM elements and their occurrence in the modal domain of the verbal element. It is interesting to note that in Romance dialects in section 4 , mesoclisis brings together $1^{\text {st }}$ person clitics and locative $t \int \partial$ and dative no. The deictic nature of tf can account for its connection with the other referential clitics; as to the dative no, we must conclude that it is treated like $1^{\text {st }}$ person clitics, inherently oblique.

As a first step, we will consider the morphological structure of pronouns. In keeping with the model proposed in Manzini and Savoia (2018), Savoia et al. (2017, 2018), specifically concerning nouns, inflectional structures are built in the syntax. Thus, inflected nouns are analysed as the result of a syntactic Merge operation that combines a lexical root with gender (feminine/masculine), other classificatory properties and number. Labels are mostly selfexplanatory, such as ' $\sqrt{ }$ ' for the category-less root (Marantz 1997) with predicative content (Higginbotham 1985), and 'N Class' to host gender and eventually number specifications. 'Infl' is the label for the vocalic morpheme which in romance varieties externalizes gender and/or number in terms of inflectional class. So, for instance, libr- 'book' in Italian combines with nominal class specifications including gender (e.g. masculine, feminine), which restricts the argument of the predicative base. A vocalic morpheme encodes properties that include both nominal class and declension class, for instance -o in libr-o 'book'. As for the plural, we assume that it corresponds to the part-whole/inclusion property, $[\subseteq]$, whereby the denotation of the root can be partitioned into subsets of individuals, as in (23). In other words, plurality denotes a subset (Chierchia 1998). 
(23)

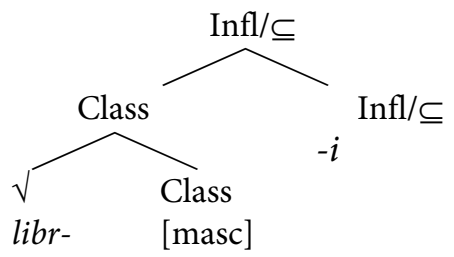

The case of clitics is interesting in the sense that their structure can be analyzed in the same way as a full noun, with the lexical base, $l$ - in the enclitic forms of Romance dialects, combined with Class and inflection, as in (24). In Albanian and generally in proclitic forms of Southern Italian varieties (see (13e) and (14e)), clitics have a simpler structure lacking the root, i.e. coinciding with the class and inflection elements, as in (25). Therefore, Romance dialects alternate two different lexical entries for clitics, according to the sentence structure, i.e. between enclitic vs. proclitic occurrence, and in the imperative between positive vs. negative form.

(24)

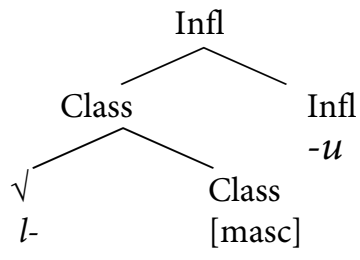

(25)

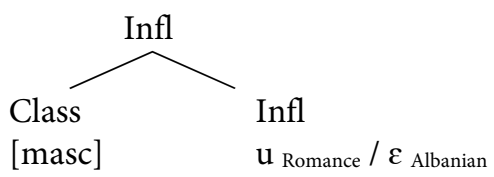

As noted, the $1^{\text {st }} / 2^{\text {nd }}$ person clitics occur both in transitive and intransitive contexts without distinguishing accusative and oblique. We conclude that they realize the oblique element, i.e. DOM lexicalization of deictic IA. It is no accident that in the clitic clusters and with respect to the verb, including imperative form, they have the same distribution of dative and locative elements. We obtain the representation in (26)

(26)

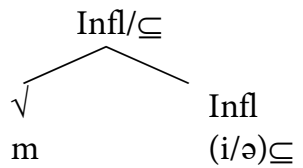

In (26) the part-whole relation characterizes oblique as well, by assuming that the inclusion relation between two arguments is the basic relation underlying prepositions and oblique case (Manzini and Savoia 2011, Franco and Manzini 2017, Savoia et al. 2019). Also in the case of verbs, they can be understood as the result of the syntactic Merge operation that combines a lexical root with voice, modal-aspectual and agreement inflections. Labels are mostly selfexplanatory, such as ' $V$ ' for the category-less root and 'Infl' for the morphemes that externalize nominal (person and number) features of the verb. We represent the internal structure of the $2^{\text {nd }}$ plural of imperative, for instance fixni 'see.pl' (Gjirokastër) in (27), where 'Mood' corresponds the imperative content. 
(27)

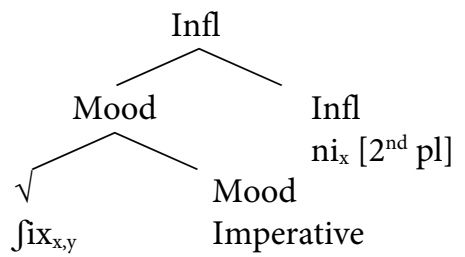

(27) combines the verbal root fix 'see', selecting two arguments, EA $x$ and IA $y$, the counterfactual property of order (Imperative) and the person Inflection $n i$, on its own saturating the EA, as in (27). The proposal to introduce a word-internal slot for the modal content is substantiated by the fact that there are languages where imperative brings along specialized types of inflection. An example at hand is provided by the variety of Shkodër, where the $2^{\text {nd }}$ person imperative of verbal roots ending in a consonant, has a short vocalic stressed nucleus differently from the otherwise coincident form of the reduced participle (Manzini and Savoia 2007), as in the comparison illustrated in (28a) for imperative vs (28b) for reduced participle.

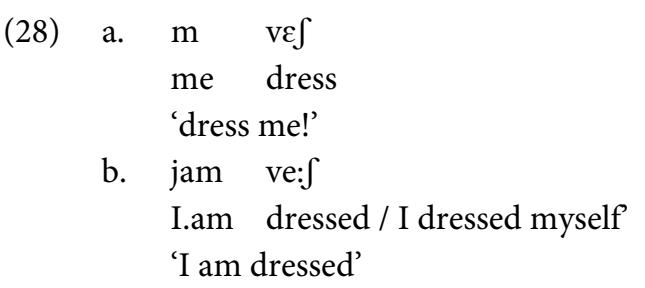

Morpho-phonological differences of this kind support the idea that mood or other aspectual/modal verbal category can be registered by formal means. In this case, the vowel duration (and its aperture degree) is involved.

A point discussed on several occasions and articles (recently in Baldi and Savoia 2019) concerns the framework we keep to, in which all lexical material, including inflectional material, is associated to interpretable contents; this proposal is not substantially different from the conception of Agree in Chomsky (2001) insofar as it expresses the identity between features under locality (Minimal Search). As a consequence, there is no Agree rule triggered by the need for a probe to interpret/value its features and, more basically, our model excludes uninterpretable features and probe-goal induced movement, i.e. the fundamental mechanisms of cartographic explanations (see Chomsky et al. 2019). Agreement works by lexicalizing phifeature bundles identifying the same argument, i.e., ultimately, denoting a single referent (Manzini and Savoia 2005, 2018).

\section{Imperative, clitics and negation}

The distribution of the OCls in imperatives highlights the relation between inherent interpretive properties of personal pronouns and the Phases, i.e. the licensing domains of the clause. Chomsky (2001) identifies phases with lexical subarrays, i.e. structures, computed at the SM and C-I interfaces as the result of the operation of Transfer. The procedure is constrained by the Phase Impenetrability Condition (PIC) in (29). The idea is that in a structure ${ }_{\mathrm{zP}} \mathrm{Z}$... [HP 
a [H YP]]], where $\mathrm{Z}$ and $\mathrm{H}$ are heads, the complement $\mathrm{YP}$ of $\mathrm{H}$ is not accessible to operations at ZP (Richards 2011).

(29) PIC

The domain of $\mathrm{H}$ is not accessible to operations at $\mathrm{ZP}$; only $\mathrm{H}$ and its edge are accessible to such operations Chomsky (2001: 14)

Chomsky $(2007,2013,2020)$ assumes the existence of two phases, CP and vP. The CP phase implies inheritance of features from the phase head $C$ to the lower head T. Furthermore "the inheritance mechanism is simplified if it is generalized to phase heads generally, not restricted to $\mathrm{C}$ but extended to $\mathrm{v}^{\star}$ as well [...] Therefore $\mathrm{V}$ (or R) must receive $\varphi$-features from $\mathrm{v}^{\star}$. It follows that just as a nominal phrase can raise to SPEC-T within CP, so it should be able to raise to SPEC-V within $v^{\star} P$ " (Chomsky 2007: 20-21). The distribution of Albanian clitics with respect to the Phases $\mathrm{CP}$ and $\mathrm{vP}$ may be depicted in the schema in (30), where the lexical verb and the $1^{\text {st }}$ person clitic $(\mathrm{PCl})$ belong to the same phase, while the $3^{\text {rd }}$ person clitic $(\mathrm{OCl})$ is associated to the $\mathrm{v}$ domain.
a. Mood/CP phase:
C
$\mathrm{PCl} / \mathrm{PCl}$
C
verb root mə / mə verb root Inflection
$\mathrm{T}$
b. vP phase:
$\mathrm{OCl} \quad \mathrm{v}$
$\varepsilon / \mathrm{i} / \mathrm{u} / \mathrm{m}-\mathrm{a}$

We are suggesting that imperatives in $\mathrm{C}$ externalize the modal operator (imperative force) by taking scope over all the lexical material. Assuming a suggestion in Roberts (2010) as regards the object clitics in Romance languages ${ }^{3}$, we may surmise that OCls are the true head of agreement for $v$ phase. If we extend this intuition to Albanian inasmuch it is endowed with $\mathrm{OCls}$, the $\mathrm{OCl}$ in mesoclisis is to be viewed as the agreement head for vP phase. Furthermore, in imperatives it preserves a position overtly associated to the vP domain. As to the hypothesis that the inflectional morpheme - ni may lexicalize $v$, we note that $v$ is accessible to the operations at $\mathrm{CP}$ and it substantially provides the morphological instantiation of phi-features licensed by $\mathrm{T}$.

Note that in Albanian varieties the clusters $1^{\text {st }} / 2^{\text {nd }} /$ dative+accusative select the $a$ form of the accusative, as in jep-m-a-ni 'give (2pl) it to me' for Gjirokastër in (3d'). In isolation the accusative form for the $3^{\text {rd }}$ singular is generally $\varepsilon$, whereas $a$ can be identified as a sandhi form of the $3^{\text {rd }}$ singular person accusative clitic. This suggests that in imperatives the sequences $m+a$ 'me-it' and $i-a$ 'him/her+it' are real clusters, confirming that no Phase boundary is involved between $m / i$ and $a$. In other words, we are induced to assume that clusters are however licensed in the C-T domain.

3 Roberts (2010: 57, with adaptations) deals with OCls as bundles of phi-features on the edge of the v phase, as for instance in (i), cf. also Mavrogiorgos (2006).

(i) a. ...le voit 'he sees him/it'

b. $\left[\mathrm{v}^{*} l e_{[i \varphi]}\left[\mathrm{v}^{*}\right.\right.$ voit $\left.\left.\left._{\mathrm{v}}\left[\mathrm{v}^{*} \mathrm{~V}, \mathrm{uV}, \mathrm{u} \varphi\right]\right]\right]\right]$ 


\subsection{DOM and cliticization in Albanian}

Let us consider the example in ( $4 \mathrm{~d}$ ') for Firmo, $\supset-m-n i-\varepsilon$ 'give it to me' instantiating both the DOM effect and mesoclisis. The possibility that lexical material could be inserted between root and inflection has been treated in the DM framework by Halle and Marantz (1994), Harris and Halle (2005), Arregi and Nevins (2018), in terms of rules manipulating the morpho-syntactic features associated to the terminal nodes of syntactic structure before inserting the lexical items. Our analysis diverges from this model on essential points, by assuming that lexical items (including inflections) are endowed with interpretable content on the basis of which they are inserted in the syntactic structure; in other words, as suggested, inflectional structures are built in syntax. This approach allows us to treat the phenomenon of mesoclisis between root and inflection, as in (31), in a natural way. Indeed, we can expect that clitics and inflectional morphemes can interact in order to lexicalize relevant interpretive properties.

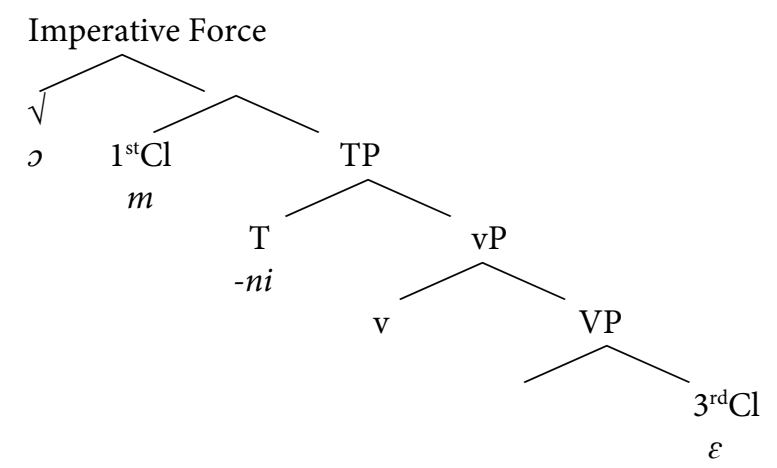

Firmo

In (31), all elements except the verbal root are able to be referred to the real world. What we see is that deictic clitics, as $m$ 'me', may occur freely in the immediate context of the verbal root, deploying its capability to be interpreted independently of the verb/event. In the varieties in (3) and (4-5), it occurs in a position immediately to the right of the root, while in the Shkoderr variety it occurs before the root. In any case, it seems to be associated to the phase of the root, conventionally identifiable with the domain of C. In (31) we label this domain Imperative force. We have tied this distribution with DOM, as far as $1^{\text {st }}$ person clitics are inserted in the string independently of their argumental role in the event ( $\mathrm{v}, \mathrm{VP})$.

The data from San Costantino in (5c') show that the mesoclisis of $m$ entails the lexicalization of the specialized inflection of $2^{\text {nd }}$ plural person $-n i$. In this dialect the $2^{\text {nd }}$ plural person of imperative in isolation has typically the inflection $-i$, coinciding with the inflection of the indicative present, as in $(32 \mathrm{a}, \mathrm{b})$ vs $(32 \mathrm{~b})$, where $-n i$ is inserted.

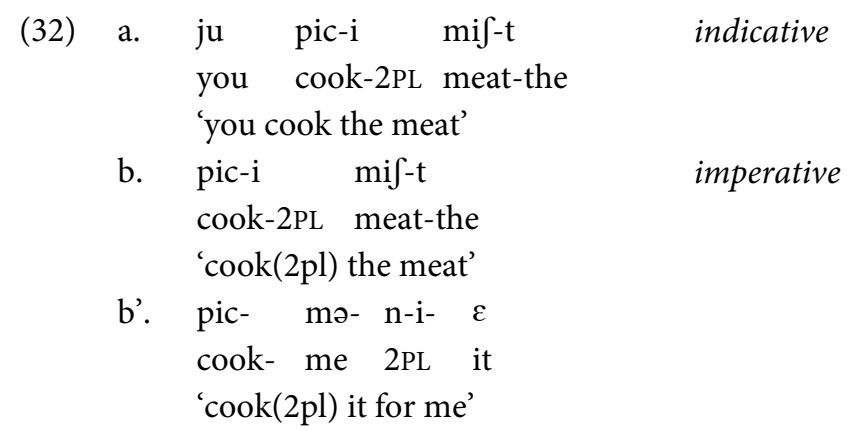


As to $-i$, it is a syncretic form occurring in different person contexts, for example in the $1^{\text {st }}$ plural of the present indicative, e.g. mbuאo-m- $i$ 'we cover', in the $3^{\text {rd }}$ person of the past, $m b u$ אo- $i$ '(s)he covered'. On the contrary, $-n-i$ is specialized for the $2^{\text {nd }}$ plural person reference. We could conclude that in imperatives its insertion is favored in order to externalize the Phase boundary between $\mathrm{CP}$ and $\mathrm{vP}$, as in (33) (see section 6.2).

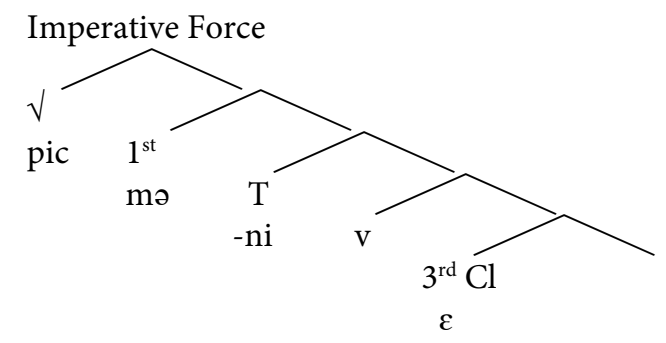

San Costantino

The $3^{\text {rd }}$ person element has the accusative morphology in the domain of the event $(\mathrm{v} / \mathrm{V})$, as shown by Arbëresh varieties where the object clitic follows - ni. Differently, in Shkodër variety, it precedes $-n i$ in the internal context and in Gjirokastër variety it is in turn placed in mesoclisis. It is reasonable to relate the distribution of the $3^{\text {rd }}$ person clitic with the fact that it needs to be licensed by $\mathrm{v}$, as a participant to the event, as usually. More precisely, in the presence of a nonveridical operator such as imperative mood, definiteness is lexicalized by licensing the pronoun out of the immediate scope of the operator. This interpretive effect is reflected in positioning the $3^{\text {rd }}$ person clitic in the licensing domain of $\mathrm{v}$, in enclisis or in mesoclisis. If that is the case, we conclude that the inflectional element $-n i$ is available also to externalize $\mathrm{v}$. This seems confirmed by the reduplicative structures of Shkodër in (7d), e.g. ncp-ni-j-a-(ni) 'give (2pl) it to him/her', suggesting that $-n i$ can occur both as the inflectional part of the verb $(\mathrm{T})$ and the lexicalization of $\mathrm{v}$, as in (34).

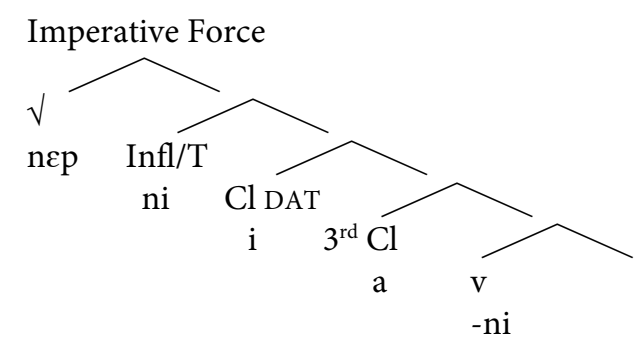

Gjirokastër

We suggest that in (34) the inflection of the verb, inherently referential ( $2^{\text {nd }}$ person), supplies the deficient $\mathrm{T}$ in identifying the person and number properties of the external argument.

In the dialect of Gjirokastër, the cluster $1^{\text {st }}$ person $+3^{\text {rd }}$ person, as in sil-m-a-ni send ( $\left.2 \mathrm{pl}\right)$ it to $m e^{\prime}$ in $\left(3 d^{\prime}\right)$, is placed between the root and the inflection. We conclude that the deictic content of the $1^{\text {st }}$ person clitic and the $2^{\text {nd }}$ plural person $-n i$ inflection are able to provide the interpretability conditions for the $3^{\text {rd }}$ person clitic, as in (35). 
(35)

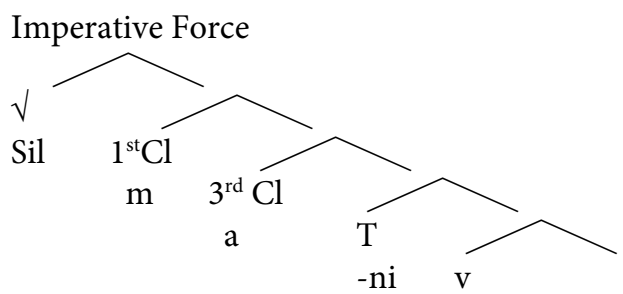

Gjirokastër

Substantially the same treatment can be extended to the data of Shkodër in (7a',b',d'), where the cluster $1^{\text {st }}$ person $+3^{\text {rd }}$ person is legitimized in the pre-verbal position, as in $m$ a ncp-ni 'give $(2 \mathrm{pl})$ it to me' in (7d'), as in the structure in (36). Again, the $1^{\text {st }}$ person clitic has referential properties sufficient to make the $3^{\text {rd }}$ person clitic interpretable in the modal domain.

(36)

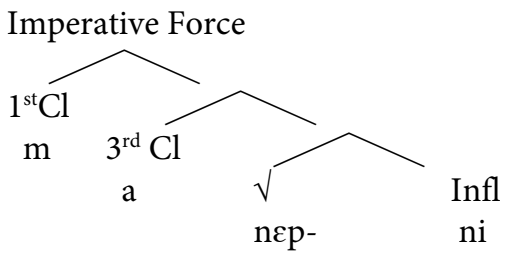

Shkodër

Synthesizing, the surface clitic order externalized in imperative contexts depends on whether the clitic is licensed by the universe of discourse ( $1^{\text {st }}$ person) or by the event $\left(\mathrm{v}-3^{\text {rd }}\right.$ person object).

\subsection{Romance varieties}

Let us consider now the Romance systems presented in sections 4 and 4.1, where mesoclisis of $1^{\text {st }}$ person and dative/locative clitics is selected only on condition that one $3^{\text {rd }}$ person clitic is present in the final position, as in (37) for Morano (from (14c)).

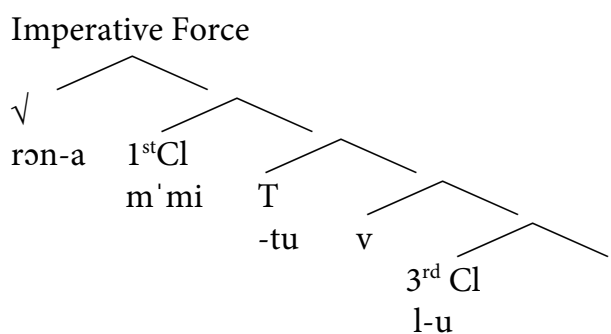

Morano

This distribution leads to the conclusion that deictic clitics, i.e. $1^{\text {st }}$ person, locative and dative, admit both mesoclisis and enclisis by virtue of their referential content, which makes it possible to interpret them in different domains. On the contrary $3^{\text {rd }}$ person clitics occur in the immediate domain of $\mathrm{v}$. We can explain this restriction by assuming that in these dialects the agreement head of $v$ is satisfied by elements endowed with referential content, i.e. deictic clitics, the $1^{\text {st }}$ person element $m i$, or $3^{\text {rd }}$ person clitics $l-u / l-a / l-i$ endowed with the definiteness base $l$ (Manzini and Savoia 2017). Also in this case, a complete referential property of OCls is required in imperative contexts so that mesoclisis is admitted only if this requirement is fulfilled. This 
seems to hold true also for other types of doubling, for instance the ones in (9) for San Marzano and in (19) for San Severo, illustrated in (38).

In the sentences in (19), reduplication of the object clitics, as di-mma- ' $m$-illa 'tell (2sg) it to me' in (19a') is confined to contexts of $2^{\text {nd }}$ singular person, where the lexicalization of the argumental properties (inflection in $\mathrm{T}$ ) is missing, as in (38).

(38) Imperative Force

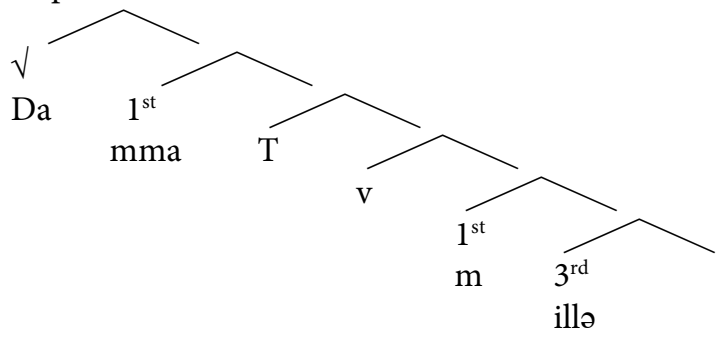

San Severo

The sentence is into the scope of the modal form (the verbal root). We find the first occurrence of the $1^{\text {st }}$ person clitic in the immediate domain of the imperative operator and the sequence 'milla 'me-it' as the specialized externalization of the participants to the event in the v Phase.

\subsection{Negative contexts}

In negative contexts, OCls are pre-verbal both in Albanian and Romance varieties. Negation can be treated as an operator "introducing a quantification over the internal argument" of the elementary event VP (Manzini and Savoia 2017: 92). This conclusion is supported by numerous phenomena in which negation and internal argument syntactically interact. Hence, the different position of clitics can mean that in the presence of negation the verb does not lexicalize the imperative force, externalized by other means, whereby the pre-verbal order valid in nonpragmatic domains is applied as suggested in (39). In San Marzano dialect, object clitics are doubled in proclisis and in enclisis in negative contexts, as shown by the example mosə $m \varepsilon$ hua$n n i-\varepsilon$ 'do not tell it to me' in (9b).

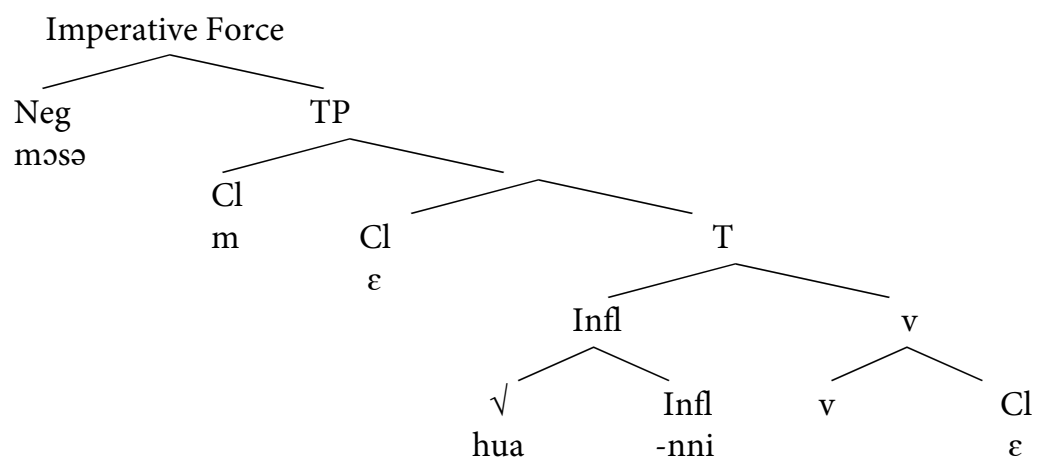

San Marzano

Negation and modal contexts (imperatives, interrogatives) are core instances of what Giannakidou $(1998,2011)$ calls non-veridical contexts "veridicality is a property of sentence embedding functions: such a function $F$ is veridical if $F p$ entails or presupposes the truth of $p$. If inference to the truth of $p$ under $F$ is not possible, $F$ is nonveridical" (Giannakidou 2011: 
1674). We have seen in Section 3 that in many languages commands addressed to the speaker or to $3^{\text {rd }}$ person are lexicalized by hortatives/subjunctives by exploiting the event variable introduced by these forms, excluding a veridical reading. In other words, both subjunctive and imperative express a relation $\mathrm{P}(\mathrm{x}, \mathrm{y})$ where the eventive properties of $\mathrm{P}$ are indefinite, not relying on truth conditions. As to negation of imperatives, typological studies document different results. Many languages allow imperative to be negated like other types of clauses (Aikhenvald 2010). This holds true for different linguistic groups, and, among Romance varieties, for example in French, in a sub-set of Italian dialects and in some Romansh varieties, as in (40).

(40) kloma $\quad$ l
call him
'call him'
bitfa kloma $\quad$ l
neg call him
'do not call him'

Donat (Grisons)

As Han (1999) stresses, negation is never about order but about the propositional content, whereby the interpretation $\neg$ Imperative Force $(p)$ is excluded. This explains why negation is incompatible with imperative forms in many languages (Alcázar and Saltarelli 2014), although in others, such as Albanian, the combination is admitted (Aikhenvald 2010). Hence, in many languages the direct negation of the imperative form is avoided and substituted by the insertion of verbal forms devoid of referential properties, available for non-veridical interpretation, such as infinitive. In Standard Italian and generally in Central and Southern Italian dialects the $2^{\text {nd }}$ singular person of negative imperative is realized by a form devoid of tense and phi-features. i.e. infinitive in (17a) for Terranova, or gerund, in (20b') for San Severo (see the survey in Manzini and Savoia 2005). In cartographic descriptions, the insertion of a form devoid of agreement features is explained as a sort of suppletion to the positive imperative of $2^{\text {nd }}$ person. Zanuttini (1997) explains this phenomenon as due to the nature of the basic form of the $2^{\text {nd }}$ singular person of imperative, understood as unable to check the mood category in presence of the negation. Also Rivero (1994) and Giannakidou (1998) explain the incompatibility of negations and imperatives assuming that the presence of the negative head blocks the movement of the verb to the Mood higher position preventing it from licensing mood.

What the data suggest is that in Romance varieties negative operator requires an indefinite lexicalization of the event, excluding phi-features specifying the EPP argument and the referential coordinates of the event. However, what we see is that in Romance dialects negative imperatives are expressed by the infinitive (or gerund), that is an indefinite non-veridical form, excluding referential phi-features and eventive coordinates; $2^{\text {nd }}$ and $1^{\text {st }}$ plural persons coincide with the indicative ones. In Albanian, the negative marker specialized for modal contexts is inserted. Finally, in all the varieties we examine here, the pre-verbal position of clitics is attested, which we have connected to the fact that in negative contexts the verb does not lexicalize the pragmatic force and the pre-verbal order is restored. In (16)-(17) we have seen that in CalabroLucanian dialects the $l$-forms of clitics are inserted in negative contexts, as in (41); $l$-accusative clitics are generally selected in negative domains, including declarative sentences (cf. Baldi and 
Savoia 2019). The definiteness root $l$ - provides a complete referential content in contexts where the pronoun is out of the scope of negative operator, as in the imperative contexts (see Manzini and Savoia 2017).

(41) Imperative Force

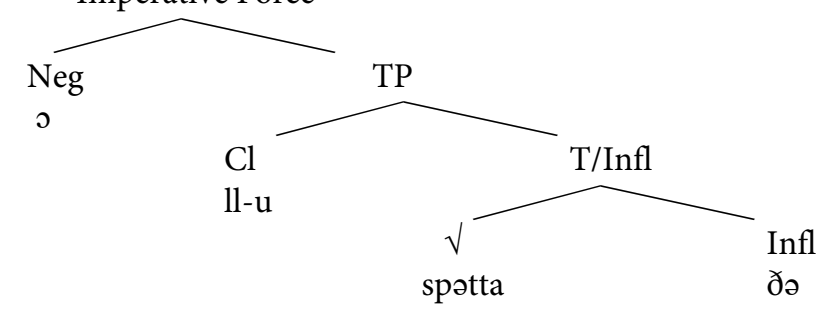

Terranova

In the case of Cardeto in (21) the infinitival inflection - $r i$ is extended to all persons of imperative being added to the $1^{\text {st }}$ plural or $2^{\text {nd }}$ plural inflection, as in (42) for non $t f-u d a-m u-r i$ 'do not give (1pl) it to her/him' (Cardeto).

$(42)$

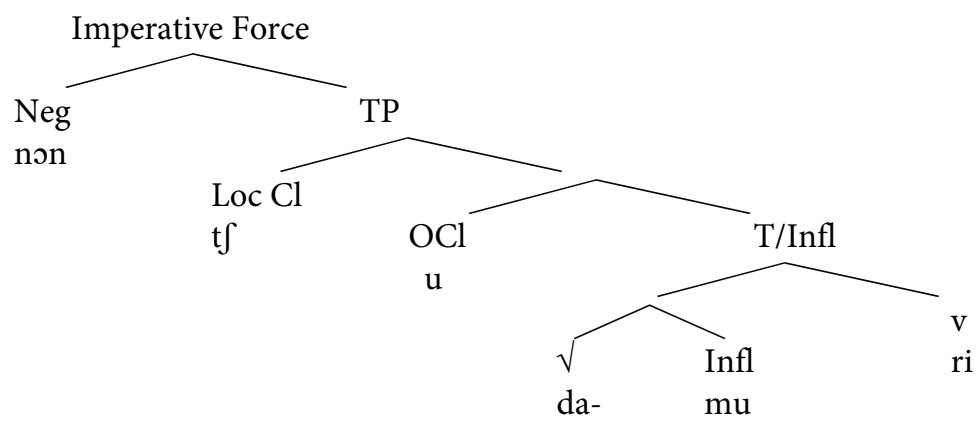

Cardeto

A possible suggestion comes from the discussion concerning (37), whereby the infinitival inflection has sufficient referential properties to satisfy the requirements of $v$ in contexts of the imperative quantification.

\section{A brief recapitulation}

Keeping the preceding discussion in mind, the distribution of OCls and the plural inflection can be connected to the externalization of the modal properties of imperative. We have assigned the initial position of the verb to the scope position corresponding to the pragmatic force and the speech act restrictions characterizing the imperative form. The non-veridical nature of the imperative sentences is highlighted by the form of the verb, that coincides with the root in the singular and, at least in a subset of contexts, also in the plural, where the root is separated from the inflection. In other words, the imperative form lexicalizes the only predicative content of the verb.

In mesoclisis structures, a type of person split emerges, whereby person clitics ( $1^{\text {st }}$ person ones) occur close to the verbal root, suggesting that they share the same domain as the root. We connect this with the fact that they are interpretable on their own, on the basis of their deictic properties. On the contrary, $3^{\text {rd }}$ person object clitics are positioned on the right of the verb and, specifically, of the $2^{\text {nd }}$ plural morphology, so reflecting the necessity for $3^{\text {rd }}$ person elements to 
be licensed in the domain of the event (v). The properties inherent in the two series of clitics account for the distributional phenomena observed in imperatives, including the fact that in some varieties mesoclisis is triggered with the $1^{\text {st }}$ person clitic and possibly with clusters. The Phase model permits to represent the distribution of verbal root, object clitics and verbal inflection in terms of principle, uncovering the different licensing domains of the two kinds of clitics and of the two parts of verbal forms, i.e. root and inflection.

\section{References}

Aikhenvald, A. Y. 2010. Imperatives and commands. Oxford: Oxford University Press.

Aissen, J. 2003. Differential object marking: Iconicity vs. economy. Natural Language \& Linguistic Theory 21: 435483.

Alcázar, A. and M. Saltarelli. 2014. The syntax of imperatives. Cambridge: Cambridge University Press.

Arregi, K. and A. Nevins. 2018. Beware Occam's syntactic razor: Morphotactic analysis and Spanish mesoclisis. Linguistic Inquiry, 49(4): 625-683.

Baldi, B., and L. M. Savoia. 2018. Morphosyntactic reorganization phenomena in Arbëresh dialects: The neuter. Quaderni di Linguistica e Studi Orientali QULSO 4: 109-130.

Baldi, B., and L. M. Savoia. 2019. Auxiliary selection in Italian dialects: Person split, OCls and raddoppiamento fonosintattico. Quaderni di Linguistica e Studi Orientali QULSO 5: 55-105.

Bárány, A. and L. Kalin. in press. Introduction. In A. Bárány and L. Kalin (eds.), Case, agreement, and their interactions: New perspectives on differential object marking, 1-25. Berlin: De Gruyter.

Bossong, G. 1991. Differential object marking in Romance and beyond. In D. A. Kibbee and D. Wanner (eds.), New analyses in Romance linguistics, 143-170. Amsterdam: John Benjamins.

Chierchia, G. 1998. Partitives, reference to kinds and semantic variation. In A. Lawson (ed.), Proceedings of Semantics and Linguistic Theory, vol. VII, 73-98. CLC Publications, Ithaca,

Chomsky, N. 2001. Derivation by Phase. In M. Kenstowicz (ed.), Ken Hale: A life in language, 1-54. Cambridge, MA: The MIT Press.

Chomsky, N. 2007. Approaching UG from below. In U. Sauerland, and H.-M. Gärtner (eds.), Interfaces + Recursion = Language? Chomsky's Minimalism and the view from semantics, 1-29. Berlin: Mouton de Gruyter.

Chomsky, N. 2013. Problems of projection. Lingua 130: 33-49.

Chomsky, N. 2020. Puzzles about phases. In L. Franco and P. Lorusso (eds.), Linguistic variation: Structure and interpretation, 163-167. Berlin: De Gruyter Mouton.

Chomsky, N., Á. Gallego, and D. Ott. 2019. Generative Grammar and the faculty of language: Insights, questions, and challenges. In Á. Gallego and D. Ott (eds.), Generative syntax: Questions, crossroads, and challenges, Special issue of Catalan Journal of Linguistics: 229-261.

Comrie, B. 1979. Definite and animate direct objects: A natural class. Linguistica Silesiana 3: 13-21.

Croft, W. 1988. Agreement vs. case marking and direct objects. In M. Barlow and C. A. Ferguson (eds.), Agreement in natural language: Approaches, theories, descriptions, 159-179. CSLI.

De Angelis, A. online. Microvariazione, diacronia e interferenza: Due case-studies dall'Italia meridionale estrema.

Dixon, R. M. 1994. Ergativity. Cambridge: Cambridge University Press.

Franco, L., and M. R. Manzini. 2017. Instrumental prepositions and case: Contexts of occurrence and alternations with datives. GLOSSA 2: 1-37

Giannakidou, A. 1998. Polarity sensitivity as (non)veridical dependency. Amsterdam: John Benjamins.

Giannakidou, A. 2011. Negative and positive polarity items. In K. von Heusinger, C. Maienborn, and P. Portner (Eds.), Semantics: An international handbook of natural language meaning, Volume 2, 1660-1712. Berlin: Mouton de Gruyter.

Halle, M., and A. Marantz. 1994. Some key features of Distributed Morphology. In: A. Carnie, H. Harley and T. Bures (eds.), Papers on Phonology and Morphology. MIT Working Papers in Linguistics 21: 275-288. 
Han, C.-H. 1999. Deontic modality, lexical aspect and the semantics of imperatives. Linguistics in the Morning Calm 4: 479-495.

Harris, J., and M. Halle. 2005. Unexpected plural inflections in Spanish: Reduplication and metathesis. Linguistic Inquiry 36: 195-222.

Higginbotham, J. 1985. On semantics. Linguistic Inquiry 16: 547-621.

Kiparsky, P. 2008. Universals constrain change; change results in typological generalizations. In J. Good (ed.), Linguistic universals and language change, 23-53. Oxford: Oxford University Press.

Kuryłowicz, J. 1964. The inflectional categories of Indo-European. Heidelberg: Carl Winter Universitätsverlag.

Ledgeway, A., N. Schifano, and G. Silvestri. 2016. The negative imperative in southern Calabria: Spirito greco, materia romanza again? Paper presented at FARM Workshop, University of Bucharest, 25-26.11.2016.

Loporcaro, M. 1995. Recessività sintattica dell'infinito e vitalità morfologica della desinenza infinitivale in alcuni dialetti del reggino. In R. Ajello, and S. Sani, Scritti linguistici e filologici in onore di Tristano Bolelli, 331-358. Pisa: Pacini.

Manzini, M. R., and L. M. Savoia. 1999. The syntax of middle-reflexive and object clitics: A case of parametrization in Arbëresh dialects. In: M. Mandalà (ed.), Studi in onore di Luigi Marlekaj, 283-328. Bari: Adriatica.

Manzini, M. R., and L. M. Savoia. 2005. I dialetti italiani e romanci. Morfosintassi generativa. Alessandria: Edizioni dell'Orso.

Manzini, M. R., and L. M. Savoia. 2007. A unification of morphology and syntax. Investigations into Romance and Albanian dialects. London: Routledge.

Manzini, M. R., and L. M. Savoia. 2011. Mesoclisis in the imperative: Phonology, morphology or syntax? Lingua 121: 1101-1120.

Manzini, M. R., and L. M. Savoia. 2017. Enclisis/Proclisis alternations in Romance: Allomorphies and (re)ordering. Transactions of the Philological Society 115: 98-136.

Manzini, M. R., and L. M. Savoia. 2018. The morphosyntax of Albanian and Aromanian varieties. Berlin/Boston: De Gruyter Mouton.

Manzini, M. R., and L. M. Savoia. Forthcoming. Person splits in Romance. Implications for parameter theory. In: A. Bárány, T. Biberauer, J. Douglas, and S. Vikner (eds.). Syntactic architecture and its consequences II: Between syntax and morphology. Berlin: Language Science Press.

Marantz, A. 1997. No escape from syntax: Don't try morphological analysis in the privacy of your own lexicon. University of Pennsylvania Working Papers in Linguistics 4: 201-225.

Mauck, S., and R. Zanuttini. 2005. The subjects of English imperatives. In C. Brandstetter, and D. Rus (eds.), Georgetown University working papers in theoretical linguistics. Volume IV, 53-85. Washington, DC: Georgetown University Department of Linguistics.

Mavrogiorgos, M. 2006. The syntax-morphology interface is at the edge: Evidence from Greek clitics. GLOW Newsletter 56.

Platzack, C., and I. Rosengren. 1998. On the subject of imperatives: A minimalist account of the imperative clause. The Journal of Comparative Germanic Linguistics 1: 177-224.

Portner, P. 2004. The semantics of imperatives within a theory of clause types. In R. Young (ed.), SALT XIV, 235252, Ithaca, NY: Cornell University.

Richards, M. D. 2011. Deriving the Edge: What's in a Phase? Syntax 14: 74-95.

Rivero, M.-L. 1994. Negation, imperatives and Wackernagel effects. Rivista di Linguistica 6: 39-66.

(1) Roberts, I. 2010. Agreement and Head Movement. Cambridge, MA: The MIT Press.

Savoia, L. M., B. Baldi, and M. R. Manzini. 2018. Sigmatic plurals in Romance varieties spoken in Italy and their interaction with -i plurals. Linguistics Beyond and Within 4: 141-160,

Savoia, L. M., B. Baldi, and M. R. Manzini. 2019. Asymmetries in plural agreement in DPs. In J. Emonds, M. Janebová, and L. Veselovská. (eds.), Language use and linguistic structure proceedings of the Olomouc Linguistics Colloquium 2018, 204-224. Olomouc: Palacký University Olomouc (ONLINE)

Savoia, L. M., M. R. Manzini, L. Franco, and B. Baldi. 2017. Nominal evaluative suffixes in Italian. In R. D’Alessandro, G. Innàccaro, D. Passino, and A. M. Thornton. (eds.), Di tutti i colori. Studi linguistici per Maria Grossmann, 283-300. Utrecht: Utrecht University Press. 
Speas, P., and C. Tenny. 2003. Configurational properties of point of view roles. In A. DiSciullo (ed.), Asymmetry in grammar, 315-344. Amsterdam: John Benjamins.

Zanuttini, R. 2008. Encoding the addressee in the syntax: Evidence from English imperative subjects. Natural Language and Linguistic Theory 26(1): 185-218. 